\title{
Oil, Gas, and Mineral Titles: Resolving Perennial Problems in the Shale Era
}

Laura H. Burney*

"Long before the full frenzy of the boom, you could see its harbingers at the Mountrail County courthouse ... and now it was the hour of the 'landmen,' the men and women whose job was to dig through courthouse books for the often-tangled history of mineral title and surface rights."

-North Dakota Went Boom, N.Y. Times MAGAZINE, Feb. 3, 2013.

\section{INTRODUCTION}

The "shale revolution" dominates the news today. ${ }^{1}$ Analysts rank

* Professor of Law, St. Mary's University. Professor Burney has written extensively on oil and gas law issues, and is a frequent speaker at energy resources conferences and courses for attorneys and other professionals in the industry. She has served as a mediator and arbitrator in oil and gas and other disputes, and has worked as an advocate or expert in oil and gas cases in several states.

1. See Talia Buford, Is Exporting Natural Gas a Problem?, Politico (Feb. 13, 2013, 4:18 AM), http://www.politico.com/story/2013/02/abundance-of-natural-gas-more-harm-than-good87533.html ("The U.S. is in the midst of a shale revolution, with fracking making accessible deposits of gas trapped deep in shale rock that a decade ago were unreachable."); Jennifer Hiller, A $21 \mathrm{st}$ Century Oil Boom in the Lone Star State, SAN ANTONIO EXPRESS-NEws (Feb. 25, 2013, 6:46 PM), http://www.mysanantonio.com/business/article/A-21st-century-oil-boom-in-the-Lone-Star-State-

4303192.php (claiming shale production will propel oil production in the United States past some other OPEC countries); Jennifer Hiller, Study: Shale Gas Boom Will Last Decades, SAN ANTONIO EXPRESS-NEwS (Mar. 1, 2013, 12:57 AM), http://www.mysanantonio.com/business/article/StudyShale-gas-boom-will-last-decades-4318224.php (mentioning the shale plays in Texas, Louisiana and Arkansas); Fracking: 365 Lee County Landowners Don't Possess Drill Rights, The FaYeTteville OBSERVER (Feb. 18, 2013, 5:26 AM), http://fayobserver.com/articles/2013/02/18/1238011 (stating that landowners will not profit "if a statewide moratorium on hydraulic fracturing is lifted"); Vicki Vaughan, Texas is On its Way to Being 'Saudi Texas', SAN ANTONIO EXPRESS-News (Feb. 17, 2013, 8:38 AM), http://www.mysanantonio.com/default/article/Texas-is-on-its-way-to-being-SaudiTexas-4284822.php (noting the vast increase in oil production thanks to shale play) [hereinafter Vaughan, Saudi Texas]. In addition to dominating the news, shale play stories can be found on YouTube and in a theater near you. See GASLAND (2010), http://www.gaslandthemovie.com (providing facts about and behind the documentary); see also PROMISED LAND (2012), available at http://focusfeatures.com/promised_land (last visited Aug. 22, 2013) (detailing the storyline of PROMISED LAND, a movie about the impact of establishing new natural gas drilling sites in a small farming community); PROMised LAND TRAILER, YouTube (Sept. 21, 2012), http://www.youtube.com/watch?v=AHQt1NAkhIo (providing a quick preview). However, not all of the news about the shale play is positive. See Anne C. Mulkern, California: Massive Shale Play Predicted to Trigger New 'Gold Rush', ENV'T \& ENERGy PUBL'G, LLC. (Dec. 5, 2012, 3:08 PM), http://www.eenews.net/public/energywire/2012/12/05/1 (noting that there are environmental concerns associated with fracking in California). 
current shale play booms as bigger than the historic East Texas and Spindletop oil discoveries. ${ }^{2}$ Texas boasts record-setting production from the Barnett, Haynesville, and Eagle Ford Shale plays. ${ }^{3}$ Prosperity has returned to Pennsylvania, site of the first oil well drilled in 1859 , and continues through the vast Marcellus Shale, which extends through several states. ${ }^{4}$ Other states, including Colorado, Montana, and North Dakota, share in the shale play success. ${ }^{5}$ The technologies responsible for the surge in production from these "tight rock" shale formations, hydraulic fracturing and horizontal wells, have revived production from others, such as the Mississippian Lime formation in Kansas. ${ }^{6}$ In fact,

2. Oil output in Texas has doubled since Eagle Ford production began and in November, 2012, reached 2.139 million barrels a day. See Vaughan, Saudi Texas, supra note 1. From January 10 until January 19, 1901, Spindletop's Lucas Geyser produced 100,000 barrels of oil per day. Robert Wooster and Christine Moor Sanders, Spindletop Oilfield, HANDBOOK OF TEXAS ONLINE (Oct. 6, 2013, 4:25 PM), http://www.tshaonline.org/handbook/online/articles/dos03. See also Vickie Vaughan, Eagle Ford Impact Pegged at \$25 Billion in 2011, SAN ANTONIO EXPRESS-NEWS (May 9, 2012, 11:38 PM), http://www.mysanantonio.com/news/local_news/article/Eagle-Ford-impactpegged-at-25-billion-in-2011-3546504.php (touting the Eagle Ford shale "as a modern-day Spindletop"); see also Chad Watt, Eagle Ford All Grown Up, FORBES (Oct. 16, 2012, 3:12 PM), http://www.forbes.com/sites/mergermarket/2012/10/16/eagle-ford-all-grown-up-2/ (grouping the Eagle Ford Shale with the Permian Basin and Bakken field as the top producers in the United States). Recent shale play has also rekindled hopes about Spindletop and untapped reservoirs previously unattainable. Emily Pickrell, Oilmen Hope to Re-tap Fabled Wealth of Spindletop Gusher, SAN ANTONIO EXPRESS-NEWS (Feb. 7, 2013, 8:32 PM), http://www.mysanantonio.com/business/article/Oilmen-hope-to-re-tap-fabled-wealth-of-Spindletop4261411.php. For a brief history of the East Texas Play and Spindletop see DANIEL YERGIN, THE PRIZE: THE EPIC QUEST FOR OIL, MONEY AND POWER 26 (1991).

3. See Vaughan, Saudi Texas, supra note 1 (declaring Texas's oil production has reached "alltime record highs"); see also Texas Oil Production Setting Record Numbers, CROSSROADS TODAY (July 12, 2013 7:05PM), http://www.crossroadstoday.com/content/news/story/Texas-Oil-ProductionSetting-Record-Numbers/3U1GKAHli0SjYTxDsL9P6Q.cspx ("A new report said Texas is now pumping more oil that some countries and a lot of it is thanks [to] the Eagle Ford Shale.").

4. "The Marcellus Shale is truly enormous, a natural wonder extending from New York to Tennessee along a swath of territory larger than Greece." Thomas E. Kurth et al., American Law and Jurisprudence on Fracking, 58 RocKY MTN. MiN. L. INST. 4-1, at § 4.06 (2012). The Marcellus shale spans across parts of Maryland, New York, Ohio, Pennsylvania, and Virginia. See Hobart King, Marcellus Shale-Appalachian Basin Natural Gas Play, Geology.com, http://geology.com/articles/marcellus-shale.shtml (mapping the Marcellus shale across various states and its varying depths).

5. Louise S. Durham, Shale List Grows, AAPG EXPLORER (July 2012), http://www.aapg.org/explorer/2012/07jul/shale_list0712.cfm. Others are considering whether to join the fracking revolution. See Aaron Sankin, California Fracking Lawsuit: Judge Slams Obama Administration, HufFINGTON POST (Apr. 9, 2013, 6:23 PM), http://www.huffingtonpost.com/2013/04/09/california-fracking-lawsuit_n_3046838.html (addressing potential environmental concerns presented by fracking); see also NEW YoRKERS AGAINST FRACKING, http://nyagainstfracking.org/ (last visited Oct. 12, 2013) (campaigning against fracking in New York and showcasing the various reasons against lifting the moratorium on fracking).

6. John Kemp, Dreaming of Bakken, Kansas Welcomes Oil Drillers, REUTERS (Jan. 8, 2013, 11:06 AM), http://www.reuters.com/article/2013/01/08/column-kemp-kansas-fracking- 
courthouses across the country have been "packed with landmen looking for additional resources."7

Along with prosperity, however, drilling booms spawn litigation booms as people seek a piece of the profits from the oil and gas pie. ${ }^{8}$ One source for disputes is the "often-tangled history" of mineral titles. 9 Landmen and other title examiners encounter convoluted transfers through deeds and other documents, and must decipher the language parties choose and courts' interpretations of those words.

As I have written, mineral deeds present a list of perennial interpretative problems, ${ }^{10}$ which create uncertainty about ownership rights in mineral estates and the proceeds from the sale of oil and gas

idUSL5E9C89J220130108.

7. Jennifer Hiller, Shale Playground in W. Texas, SAN ANTONIO ExPRESS-NEWs (Jan. 10, 2013, 11:50 AM), http://www.mysanantonio.com/business/article/Shale-playground-in-W-Texas4180979.php.

8. See Laura H. Burney, Interpreting Mineral and Royalty Deeds: The Legacy of the OneEighth Royalty and Other Stories, 33 ST. MARY's L.J. 1, 2 (2001) (noting nineteenth century oil boom that presented title perfection issues) [hereinafter Burney, Interpreting Mineral and Royalty Deeds]; see also Review of Emerging Resources: U.S. Shale Gas and Shale Oil Plays, U.S. ENERGY INFO. ADMIN. 5-6 (July 2011), available at http://www.eia.gov/analysis/studies/usshalegas/pdf/usshaleplays.pdf (noting that all across the United States shale success is popping up); Daniel Gilbert \& Kris Maher, Shale Gas Fuels Legal Boom: Fights Over Underground Rights Confound Companies, Pennsylvania Landowners, WALL $\begin{array}{llll}\text { STREET JOURNAL (Oct. 2011), } & \text { 31, }\end{array}$ http://online.wsj.com/article/SB10001424052970204505304577003960524923098.html ("The natural-gas boom in Pennsylvania is stoking legal battles over who owns gas that was worthless until a few years ago but now holds the promise of great wealth.").

9. Chip Brown, North Dakota Went Boom, N.Y. Times MAgazine (Jan. 31, 2013), http://www.nytimes.com/2013/02/03/magazine/north-dakota-went-

boom.html?pagewanted=all\&_r=0. Landmen and other title examiners must "untangle" and trace title through deeds, wills and other proceedings affecting transfers of property to locate current owners. See Zain Shauk, Keystone XL Work Veers onto Wrong Land, FUEL FIX, (Jan. 28, 2013, 1:46 PM), http://fuelfix.com/blog/2013/01/28/keystone-xl-plans-take-work-onto-wrong-land/ (describing effect of mistakes in determining ownership for Keystone XL pipeline). That process raises a host of title issues not addressed in this article. See, e.g., Capps v. Weflen, 826 N.W.2d 605, 609 (N.D. 2013) (noting that a myriad documents and statutes affect mineral titles, such as dormant mineral acts in some states).

10. See generally Laura H. Burney, Oil, Gas \& Mineral Conveyances: The Perennial Problems (And How to Avoid Them), Paper Delivered at the Rocky Mountain Mineral Law Foundation Oil \& Gas Law Short Course (Oct. 25, 2012) (paper on file with the Kansas Law Review) (examining interpretive problems presented by mineral deeds and describing the courts' methods of dealing with them) [hereinafter Burney, Oil, Gas \& Mineral Conveyances]. Mineral titles create problems not encountered in typical real property transactions, such as the sale of a home, where "title companies" search records and provide detailed information about title issues; in the oil patch the duty to interpret mineral titles falls to landmen and oil and gas attorneys who write title opinions. See generally Terry E. Hogwood, The Myth of the Cured Title Opinion, 49 Rocky MTN MIN. L. Found. J. 345 (2012) (describing steps taken by landmen and title attorneys to cure oil and gas titles). 
production. ${ }^{11}$ Although the list is long, in this article I address the following: (1) deeds with conflicting fractions; (2) the "mineral or royalty" question; (3) the application of the common law "rule against perpetuities" to non-participating royalties, a common interest in the oil patch; (4) the meaning of "minerals"-does it include oil and gas?; (5) the executive's duty to lease; and (6) deed interpretation versus "reformation."

Recent cases have clarified some issues and complicated others. Regarding conflicting fractions, addressed in Part II, Texas cases have rejected the controversial "two-grant" doctrine they created in favor of a four-corners approach. As part of this approach, opinions have acknowledged but not embraced the "estate misconception." The estate misconception reflects the legacy of the traditional $1 / 8$ landowner's lease royalty and its effect on drafting and interpreting mineral and royalty deeds. $^{12}$

Determining whether a deed created a mineral or a royalty interest, discussed in Part III, has presented a frequent challenge for title examiners and courts. A goal courts should embrace for resolving this and other perennial issues is title stability. ${ }^{13}$ Obtaining this goal requires interpretative approaches that increase transferability by decreasing claims on property rights. ${ }^{14}$ Approaches that focus on extrinsic evidence produce case-by-case results and detract from title stability. Instead, to promote this prized policy in the oil patch, courts should strive to view

11. Burney, Interpreting Mineral and Royalty Deeds, supra note 8, at 2 (noting mineral deed interpretation problems).

12. Infra Part II.A.2.b; see also Laura H. Burney, The Regrettable Rebirth of the Two-Grant Doctrine in Texas Deed Construction, 34 S. TEX. L. REV. 73, 87-89 (1993) (outlining the "estate misconception" and its effect on drafting deeds) [hereinafter Burney, The Regrettable Rebirth].

13. See, e.g., Moser v. U.S. Steel Corp., 676 S.W.2d 99, 103 (Tex. 1984) (ruling prospectively only to avoid title confusion based upon previous decisions); accord Rucker v. DeLay, 289 P.3d 1166,1173 (Kan. 2012) (overruling the application of the rule against perpetuities in regards to interests reserved in the grantor to promote title stability). See also Spurlock v. Santa Fe Pac. R.R. Co., 694 P.2d 299, 308 (Ariz. Ct. App. 2012) (finding the term "minerals" to be unambiguous and expansive for policy reasons); Dunham v. Kirkpatrick, $101 \mathrm{~Pa}$. 36, 40 (1882) (looking to the common meaning of "minerals" to determine whether oil and gas was included in a reservation); 1 Eugene Kuntz et AL, A TREATise ON THE LAW OF OIL AND GaS § 13.3, at 375-85 (1962) (promoting the idea that when there is a general severance of mineral estate, the entire estate should be severed to promote stability); JoHn S. LOWE ET AL., CASES AND MATERIALS OIL AND GAS LAW 496 (6th ed. 2012) (preferring an expansive definition of "other minerals" because it avoids case-bycase searches for the parties' intent, which contributes to title stability).

14. Laura H. Burney, A Pragmatic Approach to Decision Making in the Next Era of Oil and Gas Jurisprudence, 16 J. ENERGY NAT. RES. \& ENVT'L. L. 1, 12 n.36 (1996) (noting that Judge Richard Posner and other scholars "have emphasized the effect of clarifying titles to land on efficiency") [hereinafter Burney, A Pragmatic Approach]. 
deeds as unambiguous and focus on language in the document. ${ }^{15}$ Consistent with that approach, in resolving the "mineral or royalty" question, the "royalty" label often guides and ends courts' inquiries. Other decisions, however, accord a chameleon-like quality to the term, allowing its meaning to change if a lease pre-dated the deed. ${ }^{16}$ Because this fact-based approach promotes the estate misconception and creates title uncertainty, it should be abandoned. ${ }^{17}$ Yet courts addressing this and other issues must debate the "precedent problem": whether decadesold decisions, even if misguided, should apply to shale era disputes in the name of preserving title stability. ${ }^{18}$

A 2012 Kansas Supreme Court decision faced the problem of misguided precedent in Rucker v. DeLay, ${ }^{19}$ discussed in Part III.B.2. In that case, the court departed from its earlier position that nonparticipating royalty interests violate the rule against perpetuities. Yet despite recognizing that most jurisdictions view non-participating royalty interests - a common interest burdening mineral estates - as vested and therefore exempt from rule against perpetuities' application, the court unnecessarily limited its ruling to reserved interests.

Pennsylvania recently faced the precedent problem regarding the meaning of "minerals." As explained in Part IV, most jurisdictions view that term as including oil and gas. In Pennsylvania, however, an 1882 case created the "Dunham rule," which determined that oil and gas are not included in that term. ${ }^{20}$ In a recent case, Butler $v$. Charles Powers Estate, ${ }^{21}$ claimants under an 1881 deed urged the court to reconsider that rule when interpreting deeds affecting modern Marcellus production. Addressing the need for title stability, writers warned that, "until the

15. Burney, The Regrettable Rebirth, supra note 12, at 78-79 (describing steps in deed interpretation process).

16. See Melton v. Sneed, 109 P.2d 509, 512-13 (Okla. 1940) (finding that the term "royalty" meant "mineral" when grant did not reference a lease); see also Hamilton v. Woll, 823 N.W.2d 754, 757 (N.D. 2012) (noting influence of Oklahoma decisions regarding the use of the term "royalty" when there is a lease on the property).

17. See infra Part III.B for the influence of other factors besides the estate misconception in a non-ownership view of mineral estates, such as Oklahoma.

18. One solution to the precedent problem is for courts to overrule misguided precedent and apply new rules prospectively only. See Moser, 676 S.W.2d at 102-03 (overruling "surface destruction" test for interpretation of phrase "other minerals" from the date of decision onward). But see Lesley v. Veterans Land Bd. of Tex., 352 S.W.3d 479, 491 (Tex. 2011) (declining to limit ruling regarding scope of executive's duty to prospective effect).

19. 289 P.3d 1166 (Kan. 2012).

20. Dunham v. Kirkpatrick, 101 Pa. 36 (1882).

21. 29 A.3d 35 (Pa. 2011). 
issue is resolved, development of the Marcellus shale in Pennsylvania may come to a near halt as a result of the concern of oil and gas companies that they have obtained leases from the wrong person." 22 Cognizant of these concerns, the Pennsylvania Supreme Court recognized the significance of public reliance on Dunham and reaffirmed it as the rule in that state. ${ }^{23}$ However, in this part, I explain that the Butler opinion should have expressly categorized the Dunham rule as a rule of property, distinct from a rule of construction, to better promote the goal of title stability. ${ }^{24}$

While the Pennsylvania Supreme Court assessed public reliance on its prior rulings, a recent Texas Supreme Court opinion fails to address that concern. Part V examines that recent case, Lesley v. Veteran's Land Board, ${ }^{25}$ which addressed the duty owed by an executive- the owner of the right to lease - to non-executive mineral owners. In that case the court held that the executive's duty may arise prior to the execution of a lease, contradicting other cases, including one of its own, which had held the duty arises only after a lease has been executed. ${ }^{26}$

Lesley also involved deed reformation versus interpretation, another issue affecting mineral titles, examined in Part VI. ${ }^{27}$ The difference is significant: when courts engage in deed interpretation, statutes of limitations do not apply because they are interpreting, not reforming, the language. ${ }^{28}$ However, when parties seek reformation claiming the words in the deed do not reflect their intent, their cause of action could be barred by limitations. ${ }^{29}$ In Lesley, the court allowed the discovery rule to extend the applicable statute, meaning reformation causes of action could remain viable for years after a deed was delivered, an approach that destabilizes land titles. ${ }^{30}$ Analyzing the Lesley issues and other perennial problems discussed below provides guidance for title examiners,

\footnotetext{
22. LOWE, supra note 13, at 509.

23. Butler v. Charles Powers Estate, 65 A.3d 885, 897 (Pa. 2013) (noting that Dunham has been the "unaltered, unwavering rule of property law" governing real estate transactions in Pennsylvania since 1882).

24. See infra Part IV.

25. 352 S.W.3d 479 (Tex. 2011).

26. Id. at 491 (contradicting In re Bass, 113 S.W.3d 735 (Tex. 2003)).

27. See infra Part VI.B.1-2.

28. See Lesley 352 S.W.3d at 485-86 (stating that while "a suit for reformation of a deed is governed by the four year statute of limitations," the court disagreed with the trial court's holding that the statute of limitations barred the claim to one-fourth of the mineral estate because there was a factual issue at the heart of the dispute).

29. Id. (citing Brown v. Havard, 593 S.W.2d 939, 943-44 (Tex. 1980)).

30. Id. at 485-68 (finding that the statutes of limitations did not bar the plaintiff's claim).
} 
drafters, ${ }^{31}$ and courts as parties seek their share—real or imagined —of profits from oil and gas production in the shale era. ${ }^{32}$

\section{II. "CONFLICTING FRACTIONS"}

\section{A. Background}

Property owners face two key decisions when creating, by grant or reservation, interests in their subsurface estates: first, whether to create a mineral interest or a royalty interest; and second, what the fractional size of that interest should be. ${ }^{33}$ This section examines courts' interpretations of the second decision and the lessons those decisions teach regarding drafting in the shale era.

\section{Why Conflicting Fractions Were Used and Why They Are Not Necessary}

Assume Owner has decided to convey to Grantee an undivided 1/2 fractional mineral interest, rather than a royalty interest. Assume also that Owner has previously leased his land to Oil Company with a

31. Throughout this article I use the term "drafter" and focus primarily on interests created in deeds by grant or reservation. However, the interpretative approaches and drafting advice I discuss applies to other documents, such as wills and trusts.

32. Writers often point to the year 2004 as the beginning of the modern shale era, when gas prices first boosted production from the Barnett and other shales. See Shale Gas: Applying Technology to Solve America's Energy Challenges 3, NAT'L ENERGY TECH. LAB., DEP'T OF ENERGY (Mar. 2011), http://www.netl.doe.gov/technologies/oilgas/publications/brochures/Shale_Gas_March_2011.pdf (recounting the timeline for shale plays); see also John D. Furlow \& John R. Hays, Jr., Disclosure with Protection of Trade Secrets Comes to the Hydraulic Fracturing Revolution, 7 TEX. J. OIL GAS \& ENERGY L. 289, 298 (2012) ("Since 1997, the growth in U.S. natural gas production and reserves from the shale plays has been exponential. In 2000, shale gas production had started to pick up, but at 0.39 trillion cubic feet (Tcf) it still represented only $2 \%$ of the $19.18 \mathrm{Tcf}$ of natural gas produced domestically that year. In 2010 , shale gas production had grown to 5.00 TcF or $23 \%$ of total U.S. natural gas production.").

Booms understandably cause grantors to regret previous grants, such as the failure to reserve minerals in land that is now subject to the shale booms. See, e.g., Kowcheck v. Pittsburgh Terminal Realization Corp., No. 2009-4328, 2011 WL 9753960, at*4-5 (Pa. Com. Pl. Civil Div. Nov. 14, 2011) (arguing that parties saying “oil and gas" does not mean Marcellus gas). "Plaintiffs' counsel writes 'the Marcellus Shale . . . was not what was intended to be transferred by fee simple back when the transfer was originally made in this matter." Id. at 4 . The booms ensure that courts will see a surge in deed cases involving regret and wishful thinking as well as the perennial issues I address below.

33. See White v. Smyth, 214 S.W.2d 967, 976 (Tex. 1948) (determining that the mineral estate was not partitionable in kind). Therefore, owners tend to grant or reserve undivided interests in their subsurface estates. These undivided interests can be expressed with fractions or percentages. As demonstrated above, conflicting fractions have spawned the most litigation. 
familiar lease form, which is commonly viewed as creating a fee simple determinable estate in the lessee. That lease is an older version requiring the lessee to pay the owner-lessor the traditional, but no longer common, $1 / 8$ landowner's royalty. ${ }^{34}$ This form lease conveys a fee simple determinable estate in all, or $8 / 8$, of the mineral estate to Oil Company, leaving Owner with a non-possessory future interest, called a possibility of reverter, in all, or $8 / 8$, of the mineral estate. ${ }^{35}$ Note that only in the oil patch will one find "the whole" defined as $8 / 8$. As described below, this phenomenon and others stem from the legacy of the $1 / 8$ royalty in older form leases. ${ }^{36}$

Today it is clear that Owner's pre-existing lease has not converted Owner's interest in the mineral estate from an interest in all $(8 / 8)$ to only $1 / 8{ }^{37}$ The lease's royalty clause entitles Owner to a share of the proceeds from the sale of the production, but does not reduce the size of his possibility of reverter. ${ }^{38}$ Owner owns a non-possessory interest in all of the minerals, but he can convey a fractional interest subject to the preexisting lease. To convey the desired undivided $1 / 2$ mineral interest, the owner should use "mineral" language and insert the fraction $1 / 2$ in the form's designated space for the fractional interest Owner intends to convey. ${ }^{39}$

\section{Why Multiclause Deed Forms Were Used and Why They Are Not Necessary}

Another fact is clear today: as a matter of law, Grantee's 1/2

34. See Burney, Interpreting Mineral and Royalty Deeds, supra note 8, at 28 (acknowledging that leases traditionally convey a $1 / 8$ royalty but notes that in Brown v. Havard, the language conveyed a lesser royalty).

35. Concord Oil Co. v. Pennzoil Exploration \& Prod. Co., 966 S.W.2d 451, 460 (Tex. 1998); 1 ERnest E. SMith \& JacQueline L. Weaver, TeXas LaW OF OIL AND GaS § 3.09(E), at 3-78 (2009) (noting that possibility of reverter is vested interest lessor retains after granting a lease); see Patrick H. Martin \& Bruce M. Kramer, Williams \& Meyers Manual of Oil and Gas TERMS 818 (Aileen M. Sterling et al. eds., 11th ed. 2000) (describing a possibility of reverter as the "interest left in a grantor or lessor after a grant of land or minerals subject to a special limitation").

36. See infra Part II.A.2.b.

37. Laura H. Burney, The Interaction of the Division Order and the Lease Royalty Clause, 28 ST. MARY's L.J. 353, 429 (1997) ("[I]t should be considered well-settled in Texas that the oil and gas lease vests $8 / 8$ ths of the oil and gas in the lessee, not $7 / 8$ ths, with the lessor retaining a possibility of reverter in $8 / 8$ ths.").

38. Id. (noting that lessor retains a possibility of reverter in all 8/8).

39. For examples of deed forms for accomplishing these goals, see, e.g., 4 ALOysius A. Leopold, TeXas PRactice SeRIEs: Land Titles and Title Examination $\$ 23.70$ (3d ed. 2012); 6 William B. Burford, WeSt's TeXas Forms: Minerals, Oil \& GAS $§ 1: 3$ (4th ed. 2012). 
undivided ownership in Owner's mineral estate entitles her to a proportionate share of the rents and royalties payable under the terms of the pre-existing lease. ${ }^{40}$ Therefore, after the conveyance, Oil Company owes $1 / 2$ of the $1 / 8$ landowner's lease royalty to Owner and the other $1 / 2$ to Grantee. ${ }^{41}$ That fact, however, eluded early courts.

\section{a. Development of the "Multiclause" Deed Form}

For example, in Caruthers v. Leonard, the court held that a conveyance subject to an existing lease did not entitle the grantee to a proportionate share of the rents and royalties payable under that existing lease. $^{42}$ In response to that decision, which was later overruled, ${ }^{43}$ a notorious deed form with multiple clauses and spaces for fractions developed to insure that Grantee received rents and royalties in proportion to the fractional mineral interest conveyed. ${ }^{44}$ Specifically, in addition to the granting clause, this deed form recited that the conveyance is made "subject to" the existing lease and "covers and includes" the specified fractional interest of rents and royalties in the existing lease. ${ }^{45}$ Another clause provided that the grantee would receive the stated fractional interest in rents and royalties payable under future leases. $^{46}$ Notably, these additional subject to and future lease clauses lacked granting clause language. ${ }^{47}$ The reason for this omission is simple: these clauses were inserted not to make additional grants, but to clarify that the grantee receives a proportionate amount of rents and

40. See, e.g., Concord Oil Co., 966 S.W.2d at 464 (finding that grantor's possibility of reverter of 1/12 of the mineral interests included a right to royalties under the lease terms); see also Burney, Interpreting Mineral and Royalty Deeds, supra note 8, at 14-15 (noting that "the deed effectively conveyed all attributes" of the mineral lease, including the right to share royalties).

41. The proportionate reduction clause in typical lease forms allows the lessee to reduce these payments proportionately to Owner and Grantee if they have leased 100 percent. See MARTIN \& KRAMER, supra note 35, at 871-72 (defining "proportionate reduction clause" and noting that the purpose of such a clause is to reduce the payments to a lessor to be in proportion to the lessor's interest).

42. 254 S.W. 779 (Tex. Comm'n App. 1923), abrogated by Hager v. Stakes, 294 S.W. 835 (Tex. 1927); see Burney, The Regrettable Rebirth, supra note 12, 86-87 (discussing the legacy of the Caruthers decision).

43. See generally Hager, 294 S.W. 835; Harris v. Currie, 176 S.W.2d 302, 306 (1943) (noting Hager's overruling of Caruthers).

44. See generally Burney, The Regrettable Rebirth, supra note 12, at 86-90 (outlining the development of the multiclause deed form).
45. Id. at 86 .
46. $I d$.
47. Id. 
royalties under any lease, existing or future. ${ }^{48}$

Courts eventually corrected the errors of Caruthers. ${ }^{49}$ But the form, which should be avoided, exists in formbooks today. ${ }^{50}$ If filled out properly, with the same fraction in every clause, it presents no problems for title examiners or courts. Unfortunately, misconceptions among laypersons and legal minds have complicated drafting and interpreting these deeds. The primary offender is the "estate misconception." 51

\section{b. Role of the "Estate Misconception"}

The estate misconception - a legacy of the "usual $1 / 8^{\text {th }}$ landowner's royalty"-describes the confusion regarding estate ownership after leasing property. ${ }^{52}$ In the example above, Owner, under the influence of the estate misconception, assumed the lease converted his ownership to $1 / 8$ in the mineral estate. ${ }^{53}$ Therefore, if Owner intended to convey an undivided $1 / 2$ interest, he multiplied that fraction by $1 / 8$ and inserted the fraction $1 / 16$ in the deed's granting clause. Because of the wording of the other post-Caruthers clauses - the subject to and future lease clauses-Owner inserted the fraction $1 / 2$ in those spaces, creating a deed with conflicting fractions. ${ }^{54}$

\section{B. Interpreting Multiclause Deeds with Conflicting Fractions: The Birth and Demise of the "Two-Grant" Doctrine}

These multiple fractions created uncertainty for title examiners.

48. Id. (noting that this form of deed was in response to correct the holding in Caruthers, which found "that when a grantee received an interest in a mineral estate that was already under lease, only a reversionary interest passed").

49. Harris v. Currie, 176 S.W.2d 302, 306 (1943) (noting that the court in Hager overruled Caruthers).

50. See, e.g., 6 William B. Burford, West's Texas Forms: Minerals, Oil \& Gas $§ 1: 2$ (4th ed. 2012) (outlining the various clauses included in a mineral deed form and cautioning against "coupling with a grant of the minerals the words 'royalty,' 'royalty interest,' or minerals 'produced and saved' from the land" to avoid conveying a royalty interest).

51. See Concord Oil Co. v. Pennzoil Exploration \& Prod. Co., 966 S.W.2d 451, 460 (Tex. 1998) (defining "estate misconception" and describing its effect on drafting); Burney, The Regrettable Rebirth, supra note 12, at 87-89 (reviewing the estate misconception).

52. See Burney, Interpreting Mineral and Royalty Deeds, supra note 8, at 15 (explaining that lessors sometimes believe that they only own 1/8 interests in the minerals after the lease when in actuality they have a possibility of reverter in $8 / 8$ ).

53. See supra Part II.A.1.

54. See Burney, The Regrettable Rebirth, supra note 12, at 86-87 (emphasizing the effect of the Caruthers decision on deed forms and noting that grantors wishing to convey a $1 / 2$ mineral interest "can do so by simply conveying a 1/2 mineral interest, regardless of an existing lease"). 
Which fraction represented the size of the interest Owner intended to convey? Or did the deed make multiple grants? Early cases provided an answer: deeds with multiple and conflicting fractions conveyed more than one interest. ${ }^{55}$ Writers labeled this interpretative approach the "twogrant" doctrine. ${ }^{56}$ In this section, I review the development and demise of the two-grant approach to interpreting deeds with conflicting fractions. The next section updates a related issue: deed forms with double or restated fractions.

\section{Concord Oil Company v. Pennzoil Exploration \& Production Company}

The two-grant doctrine arose in Texas, where the multiclause deed form originated. Texas courts adopted this interpretative approach for multiclause deed forms with conflicting fractions beginning in the 1940s. ${ }^{57}$ The last supreme court case to address the two-grant doctrine is a 1998 opinion, Concord Oil Co. v. Pennzoil Exploration \& Production Co. ${ }^{58}$

In Concord Oil, courts were confronted with this deed: a 1937 conveyance of a mineral interest with the fraction 1/96 in the granting clause and the fraction $1 / 12$ in a subsequent clause. ${ }^{59}$ At the time, the grantor owned a $1 / 12$ mineral interest in the property, which was burdened by a pre-existing lease providing for a $1 / 8$ landowner's royalty. ${ }^{60}$ Notably, the deed through which the grantor had received his $1 / 12$ mineral interest a year earlier was the same as the 1937 deed form but the fraction 1/12 appeared in both clauses. ${ }^{61}$

By the 1990s, Pennzoil owned the grantor's interest, if any, under the

55. Some cases viewed these deeds as granting one fraction at delivery of the deed that expanded upon expiration of the existing lease. See, e.g., Jupiter Oil Co. v. Snow, 819 S.W.2d 466, 467 (Tex. 1991) (noting that, upon termination of the lease, the grantee's interest "expanded into a full one-half [mineral interest] by operation of law"); see also Burney, The Regrettable Rebirth, supra note 12, at 92-94 (discussing the "expansion facet" and related decisions, including Jupiter Oil).

56. See Concord Oil Co. v. Pennzoil Exploration \& Prod. Co., 966 S.W.2d 451, 454 (Tex. 1998) (discussing the trial court's reliance on the two-grant doctrine in its decision and defining the doctrine); 2 Howard R. Williams \& Charles J. MeYers, Oil and Gas LaW § 327.2 (2012); Tevis Herd, Deed Construction and the "Repugnant to the Grant" Doctrine, 21 TEX. TECH L. REV. 635, 651 (1990).

57. Burney, The Regrettable Rebirth, supra note 12, at 90.

58. 966 S.W.2d 451

59. Id. at 453 .

60. Id.

61. Id. 
1937 deed, and Concord Oil owned the grantee's interest. ${ }^{62}$ Just as today's shale plays are spawning lawsuits over mineral deeds delivered decades ago, renewed production on property covered by the 1937 deed prompted Pennzoil to sue Concord Oil in 1993.

Pennzoil relied on precedent establishing the two-grant approach for interpreting multiclause deeds with conflicting fractions. Under that approach, Pennzoil argued that the 1937 deed had conveyed a 1/96 mineral interest and a 1/12 interest in rents and royalties under an existing lease, which had terminated. Therefore, Pennzoil claimed that Concord Oil, as successor to the grantee, owned only a 1/96 interest in the mineral estate, meaning Pennzoil owned the grantor's remaining interest. Concord Oil, on the other hand, argued that the 1937 deed had conveyed the grantor's entire 1/12 interest and Pennzoil had received nothing through its chain of title. ${ }^{63}$

The trial court and court of appeals agreed with Pennzoil. ${ }^{64}$ Eventually, however, the Texas Supreme Court ruled in favor of Concord Oil, holding that the conflicting fractions could be harmonized from the four-corners of the document. In light of the particular language of the 1937 deed, the court held it conveyed a single $1 / 12$ mineral interest. ${ }^{65}$

However, because the opinion was a plurality, with concurring and dissenting opinions, the fate of the two-grant doctrine remained unclear. $^{66}$ Concord Oil had urged the court to reject the two-grant doctrine and embrace the estate misconception as the explanation for conflicting fractions in multiclause deed forms. As explained above, that misconception, which emanates from the typical 1/8 landowner's royalty, explains why the conflicting fractions follow a pattern: they are multiples of $1 / 8$. Typically, drafters multiplied the intended fraction by $1 / 8$ and

62. Id. at 453-54 (noting that Concord Oil Company's claim was brought through the grantee of the 1937 deed and that the 1937 grantor conveyed another mineral deed in 1961 which was subsequently conveyed to Pennzoil Exploration and Production Company).

63. Id. at 454 .

64. Concord Oil Co. v. Pennzoil Exploration \& Prod. Co., 878 S.W.2d 191, 197 (Tex. App. 1994) (rejecting Concord's reading of the deed to convey two separate estates), rev'd, 966 S.W.2d 451 (Tex. 1998).

65. Concord Oil Co., 966 S.W.2d at 453.

66. The opinion breaks down to a 4-1-4 decision. Id. at 454 . The plurality found that the deed conveyed a single 1/12 mineral interest and harmonized the conflicting fractions within the deed. Id. (plurality opinion). The concurring opinion by Justice Enoch agreed that only a single estate was created but wrote separately to emphasize the overconveyance that would occur if the dissent's interpretations were used. Id. (Enoch, J., concurring). The dissent argued for the "two-grant" doctrine to determine that two estates were created, "a 1/96 perpetual interest in the minerals, and a $1 / 12$ interest in rentals and royalties ...." Id. at 465 (Gonzalez, J., dissenting). 
inserted that number in the granting clause. Indeed, early case law sanctioned that approach. ${ }^{67}$

The 1937 Concord Oil deed followed the pattern: 1/96 in the granting clause $=1 / 8$ times $1 / 12$ (the fraction in the subsequent clause) ${ }^{68}$ As another example, the deed at issue in a 1991 Texas Supreme Court case, Luckel $v$. White, contained the fractions $1 / 4$ in the subject to and future lease clauses, but the smaller fraction $1 / 32$ in the granting clause $(1 / 4$ times $1 / 8=1 / 32){ }^{69}$ As noted in Concord Oil, in light of the language appearing in the subsequent clauses, that fraction, rather than the smaller fraction in the granting clause, reflects the drafter's intent about the size of the interest the grantor intended to convey.

\section{a. The Court Declined to Follow the Kansas Approach Regarding the Estate Misconception}

To convince the Texas court to incorporate the estate misconception into the interpretative process, Concord Oil pointed to Kansas decisions. Specifically, in Shepard v. John Hancock Mutual Life Insurance Co., the Kansas Supreme Court construed a reservation in a deed that described the size of the interest as "an undivided $1 / 4$ of the landowners [sic] $1 / 8$ royalty, or, $1 / 32$ of the interest in and to all oil, gas or other minerals ...."70 The court held the grantor had reserved a 1/4 mineral interest. $^{71}$ In reaching this conclusion, the court incorporated into its interpretative process the pervasive confusion among "not only persons in the petroleum industry" but with courts:

As the most common leasing arrangement provides for a one-eighth royalty reserved to the lessor, the confusion of fractional interests stems

67. Tipps v. Bodine, 101 S.W.2d 1076, 1079 (Tex. Ct. App. 1937); see also Concord Oil Co., 966 S.W.2d at 464-65 (Tex. 1998) (Enoch, J., concurring) (blessing the use of different fractions to convey a single interest); see also Burney, The Regrettable Rebirth, supra note 12, at 102 (noting the reliance on Tipps in interpreting multiclause deeds).

68. Concord Oil Co., 966 S.W.2d at 453.

69. 819 S.W.2d 459, 461 (Tex. 1991). For a summary of the Luckel decision, see Burney, Interpreting Mineral and Royalty Deeds, supra note 8, at 9-11 (rejecting the "granting clause prevails" standard under Alford and instead relying on the presence or absence of a future lease clause in determining the intent of the parties and the fraction conveyed).

70. 368 P.2d 19, 21 (Kan. 1962). The Shepard deed was not a multiclause deed form, but it contained multiple fractions. The Shepard deed form involved "double and restated" fractions discussed in the next section. See infra Part II.C.

71. Id. at 27. A preliminary issue the court addressed was whether the interest was mineral or royalty. That aspect of the decision is discussed later in this article (the Kansas Supreme Court's recent decision in Rucker). 
primarily from the mistaken premise that all the lessor-land-owner owns is a one-eighth royalty. In conveying minerals subject to an existing lease ... mistake is often made in the fraction of the minerals conveyed by multiplying the intended fraction by one-eighth.

In Concord Oil, however, the Texas Supreme Court declined to fully follow the Shepard approach. Instead, the court noted the estate misconception, but viewed it as "instructive, but not dispositive." 73 In fact, the court declined to adopt any bright-line rules for this interpretative issue, focusing instead on the lack of any two-grant language in the 1937 deed. $^{74}$

\section{b. Guidelines from Concord Oil's "Four-Corners" Approach}

Yet, as I wrote in an earlier article, the Concord Oil opinion provided "useful guidance to title examiners" for interpreting multiclause deeds:

First, according to the opinion, a deed with multiple fractions should not be interpreted as making two grants unless express language to that effect appears in the deed. Such language would include the phrases 'separate from' or 'in addition to,' phrases which were absent from the Concord deed. Notably, [the additional clauses in multiclause deed forms] do not contain such granting language. Therefore, multiclause deed forms should rarely, if ever, be interpreted as making separate grants.

Because of the multiple opinions in Concord Oil, title examiners remained cautious about interpreting multiclause deed forms with conflicting fractions. The concurring opinion created particular concern by focusing on the future lease clause. ${ }^{76}$ In his opinion, Justice Enoch

72. Id. at 26 (citing Magnusson v. Colorado Oil \& Gas Corp., 331 P.2d 577, $583-84$ (Kan. 1958)); see also Burney, Interpreting Mineral and Royalty Deeds, supra note 8 , at 22 (noting the pervasiveness of the $1 / 8$ royalty in other jurisdictions). Shepard did not involve a multiclause deed form; rather, the language fits the "restated" or "double fraction" problem I address in Part II.C.; see also Heyen v. Hartnett, 679 P.2d 1152, 1157-58 (Kan. 1984) (construing deed with fractions 1/16 and $1 / 2$ as conveying an undivided $1 / 2$ mineral interest).

73. Concord Oil Co., 966 S.W.2d at 460.

74. Id. at $460-61$.

75. Burney, Interpreting Mineral and Royalty Deeds, supra note 8, at 16.

76. Concord Oil Co., 966 S.W.2d at 464 (Enoch, J., concurring) ("Further, we were wrong to conclude that the 'subject to' clause of the Crosby deed includes future leases."). For a complete analysis of the concurring opinion, see Burney, Interpreting Mineral and Royalty Deeds, supra note 8, at 17. Justice Enoch was also concerned with the "overconveyance" issue. See Concord Oil Co., 966 S.W.2d at 464 (Tex. 1998) (Enoch, J., concurring); see also Burney, Interpreting Mineral and Royalty Deeds, supra note 8, at 17 (explaining that a two-grant interpretation of the deed would result in the grantor conveying more than he owned, which he cannot do). 
criticized the plurality opinion for having emphasized a future lease clause in the deed as the basis for concluding the 1937 deed conveyed a $1 / 12$ interest. $^{77}$ However, the plurality opinion adopted a four-corners approach and placed no significance on the presence or absence of any clause, particularly a future lease clause. On the contrary, that opinion states that the "decision in this case does not depend on the presence or absence of a 'future lease' clause, which the court of appeals found dispositive." 78

\section{Post-Concord Oil Decisions: The Demise of the "Two-Grant" Doctrine}

Despite these words from the Texas Supreme Court about the relative insignificance of a future lease clause, a post-Concord Oil appellate opinion considered it determinative. Neel v. Killam Oil Co. ${ }^{79}$ involved a multiclause deed form that departed from the typical pattern. Specifically, in the $1945 \mathrm{Neel}$ deed, the larger fraction 1/2 appeared in the granting clause and subject to clause, and the smaller fraction 1/16 appeared in the future lease clause. ${ }^{80}$ The parties agreed the interest was a royalty interest, rather than a mineral interest. ${ }^{81}$ Regarding the size of the interest, grantee's successor argued the deed conveyed a 1/2 royalty, which would entitle the grantee to $1 / 2$ of the royalty reserved in any existing or future leases. ${ }^{82}$ To counter assertions that the granting clause and future lease clause made separate grants, the grantee pointed to this sentence in the deed's granting clause: " $[t]$ his grant shall run forever." ${ }^{, 83}$ The controversy arose after the existing lease, with the typical $1 / 8$ landowner's royalty, terminated and new leases were executed providing for a $1 / 4$ royalty. ${ }^{84}$ The court of appeals ruled against the grantee, holding the grantee was entitled to a fixed 1/16 interest in production under the new leases as provided in the future lease clause. ${ }^{85}$ In other

\footnotetext{
77. Concord Oil Co., 966 S.W.2d at 463-64 (Enoch, J., concurring).

78. Id. at 458-59 (plurality opinion).

79. 88 S.W.3d 334 (Tex. App. 2002), disapproved of by Hausser v. Cuellar, 345 S.W.3d 462, 469-70 (Tex. App. 2011).

80. Id. at 339 .

81. Id. at 339-40. The parties disagreed about whether this royalty interest was a fixed $1 / 16$ or a $1 / 2$ royalty that entitled the owner to $1 / 2$ of the royalty reserved in any lease. This "fixed" vs. "of" royalty issue is common and addressed in Part II.C of this paper (double and restated fractions).

82. Id. at 340 .

83. Id.

84. Id.

85. Id. at 341. Neel was heard by the Fourth Court of Appeals in San Antonio, the same court
} 
words, in Neel the court reverted to the two-grant doctrine. ${ }^{86}$

In reaching this conclusion, the Neel court cited Concord Oil and Luckel, explaining that those cases required it to seek the parties' intent from the four corners of the document. ${ }^{87}$ However, the Neel opinion omits any review of the two-grant saga, or of the specifics from Concord Oil, such as the court's admonition that to create separate grants a deed should contain clear evidence of such intent. Had the Neel court followed Concord Oil's guidance, the deed would have been interpreted as conveying the $1 / 2$ "of" royalty forever as set forth in the granting clause. The estate misconception explains the fraction in the future lease clause: $1 / 16$ reflects the amount of production owed to the owner of a royalty entitled to $1 / 2$ of the $1 / 8$ royalty reserved in the typical lease royalty clause. $^{88}$

Although the Texas Supreme Court declined to review Neel, a recent opinion from the same court of appeals "disapprove[d] of [its] analysis in Neel." 89 Hausser v. Cuellar involved a multiclause deed form that, like the deed in Neel, contained conflicting fractions that departed from the Concord Oil pattern. ${ }^{90}$ In Hausser, the clauses provided as follows: granting clause: $1 / 2$; subject to clause: $1 / 2$; future lease clause: $1 / 16^{91}$ After determining that the deed conveyed a royalty interest, the court considered whether it was a fixed $1 / 16$ or a $1 / 2$ royalty interest that entitled the owner to $1 / 2$ of the $1 / 4$ landowner's royalty in new leases on the property. ${ }^{92}$ In adopting the $1 / 2$ royalty option, the court cited its 2006 opinion in Garza v. Prolithic Energy Co., and explained its analysis as

that decided Concord prior to its review by the Supreme Court. Burney, Oil, Gas \& Mineral Conveyances, supra note 10, at 24-25.

86. Burney, Oil, Gas \& Mineral Conveyances, supra note 10, at 24-25.

87. Neel, 88 S.W.3d at 339-40; Burney, Oil, Gas \& Mineral Conveyances, supra note 10, at 24-25 (opining that Luckel overruled Alford's "granting clause prevails" approach to multiclause deeds with conflicting fractions but failed to clearly articulate the interpretative approach it had adopted).

88. See supra Part II.A.2.b.

89. Hausser v. Cuellar, 345 S.W.3d 462, 470 (Tex. App. 2011) (pet. denied). In disapproving, the court pointed to the Neel opinion's reliance on a previous deed, which could suggest the court approved of Neel's focus on the future lease clause. Id. Fortunately, the Hausser opinion embraced Concord Oil's guidance and cited one of its previous opinions, Garza, which clearly rejected the two-grant doctrine and incorporated the estate misconception into its analysis. See id. at 470-71 (citing Garza v. Prolithic Energy Co., 195 S.W.3d 137, 145 (Tex. App. 2006) (pet. denied)) (noting the conflicting fractions arise due to the typical $1 / 8$ royalty and confusion about what grantors actually own).

90. Id. at 470-71.

91. Id. at 465,468 .

92. Id. at 470-71. 
follows: "As in Garza, our decision is consistent with Concord Oil Co. because the [Hausser] deed does not contain any language suggesting two differing estates were being conveyed. Rather, the [Hausser] deed, like the deeds in Garza, involves a single conveyance with fixed rights." 93

A dissenting opinion in Hausser argued that the future lease clause should have controlled. ${ }^{94}$ However, in light of the majority's disapproval of Neel, its adherence to Concord Oil's guidelines, and other recent appellate court decisions that acknowledge the role of the estate misconception, ${ }^{95}$ the two-grant doctrine should disappear in Texas. Fortunately, other jurisdictions have wisely declined to adopt Texas's approach. $^{96}$ Therefore, title examiners may report, without exaggerating, the death of the two-grant doctrine for interpreting multiclause deeds with conflicting fractions in the shale era. Unfortunately, as described in the next section, court opinions have not sufficiently incorporated the estate misconception or the "legacy of the $1 / 8^{\text {th }}$ royalty" into the interpretative process for related issues: deeds with double or restated fractions.

\section{C. "Double" or "Restated" Fractions-The Legacy of the "Usual 1/8 th Landowner's Royalty"}

Writing before the shale era, I addressed these two interpretative issues: how should courts interpret deeds when the fractional interest conveyed or reserved is expressed (1) as a double fraction, such as " $1 / 2$ of $1 / 8$," or (2) as a restated fraction, such as "an undivided $1 / 2$ non-

93. Id. at 470 (citing Garza v. Prolithic Energy Co., 195 S.W.3d 137, 146 (Tex. App. 2006); Concord Oil Co. v. Pennzoil Exploration \& Prod. Co., 966 S.W.2d 451, 457 (Tex. 1998)).

94. Id. at 472-73 (Marion, J., dissenting). Note that the same judge wrote the majority opinion in Neel v. Killam Oil Co., Ltd., 88 S.W.3d 334, 337 (Tex. App. 2002), disapproved of by Hausser, 345 S.W.3d at 470.

95. See Hamilton v. Morris Res., Ltd., 225 S.W.3d 336, 343-44 (Tex. Ct. App. 2007) (holding that although there were differing fractions in the deed, only a single interest was actually conveyed); Garza, 195 S.W.3d at 145 (noting the "problematic conflict between the granting of a mineral interest and a future lease provision appearing to convey a smaller royalty interest"); see also Coates Energy Trust v. Frost Nat'l Bank, No. 04-11-00838-CV, 2012 WL 5984693, at *6-7 (Tex. App. Nov. 28, 2012) (relying on Hausser in determining the fraction conveyed); Hernandez v. El Paso Prod. Co., No. 13-09-184-CV, 2011 WL 1442991, at *4 (Tex. Ct. App. Apr. 14, 2011) (taking notice of the estate misconception).

96. Burney, Oil, Gas \& Mineral Conveyances, supra note 10, at 24 (describing the courts' methods of dealing with mineral deeds); see also Burney, Interpreting Mineral and Royalty Deeds, supra note 8, at 23 ("[T] he Arkansas Supreme Court considered the issue that led the Texas courts down the path to the creative two-grants rule...") (quoting Owen L. Anderson, Recent Developments in Nonregulatory Oil and Gas Law, 45 InST. ON OIL \& GAS L. \& TAX’N § 1.03[4], at 1-14 (1994)). 
participating royalty (being equal to, not less than an undivided 1/16)." ${ }^{, 97}$ In one article, I note courts' failure to address the "legacy of the usual $1 / 8^{\text {th }}$ landowner's royalty," which contributes to the estate misconception, and its effect on drafting and interpreting double and restated fractions. ${ }^{98}$ Because parties focused on that royalty, they expressed fractions with a double fraction, where one was invariably $1 / 8$, or by restating with a fraction equal to a multiple of $1 / 8$, as in the restated example above. ${ }^{99}$ Rather than analyze that legacy in light of other language in the deed, courts tended to ignore it or merely multiply the fractions.

For example, in a 1984 Texas Supreme Court case, Alford v. Krum, the multiclause deed contained a double fraction, $1 / 2$ of $1 / 8$ in the granting clause. ${ }^{100}$ The court viewed that clause as conveying a 1/16 interest, without noting or analyzing this mode of expressing that single fraction. ${ }^{101}$ This phenomenon, like the use of the fraction $8 / 8$ to express the term "all," appears only in the oil patch. And again, the legacy of the usual $1 / 8$ royalty explains the practice since one of the two fractions is invariably the traditional 1/8 landowner's royalty. Yet in Alford and other cases, court opinions multiply the fractions without analyzing the reason for the formula.

Before Alford, proponents of the analysis approach had argued that courts should incorporate the legacy of the $1 / 8$ royalty into the interpretative process for these fractional issues. ${ }^{102}$ Under such an approach, the double or restated fractions "should not be multiplied, but analyzed to determine the parties' intent." "103 Not all commentators agree with this approach, however. Specifically, the Williams \& Meyers

97. Burney, Interpreting Mineral and Royalty Deeds, supra note 8, at 23-28; Burney, The Regrettable Rebirth, supra note 12, at 89-97. The restated language in the example appeared in Brown v. Havard, 593 S.W.2d 939, 942 (Tex. 1980) (holding deed ambiguous, which required remand to trial court).

98. See generally Burney, Interpreting Mineral and Royalty Deeds, supra note 8.

99. See supra text accompanying note 35. See also Brown, 593 S.W.2d at 940 (finding the deed in question restated the royalty as "[b]eing equal to, not less than an undivided 1/16th").

100. 671 S.W.2d 870, 873 (Tex. 1984), overruled by Luckel v. White, 819 S.W.2d 459 (Tex. 1991).

101. Id. at 873-74. Alford adopted the "granting clause" prevails rule for the multiclause deed problem, but was subsequently overruled by Luckel, 819 S.W.2d at 461.

102. Burney, Interpreting Mineral and Royalty Deeds, supra note 8, at 24 (citing Ernest E. Smith, Conveyancing Problems, State Bar of Tex., Advanced Oil, Gas, \& Mineral Law COURSE G, G-2 (1981)).

103. Id. at 25. Not all commentators agree with this approach. See 2 HowARD R. WILLIAMS \& Charles J. Meyers, OIL AND Gas LaW § 327.3, at 94.1 (2012) [hereinafter 2 Williams \& MEYERS]. 
Treatise argues that double fractions should be multiplied under a plain meaning approach to document interpretation. ${ }^{104}$ As described below, recent court opinions also reflect contradictory opinions in resolving these disputes.

\section{Shale Era Cases}

Demonstrating that shale-production surges produce title-litigation surges, Texas courts recently have addressed several disputes involving double and restated fractions. Most of these cases involve the grant or reservation of royalty interests in which the dispute centers on one question: whether the deed created a "fixed" or an "of" royalty interest. A "fixed" royalty entitles the owner to a set share of the proceeds from the sale of production, regardless of the fractional size of the landowner's royalty in any lease. ${ }^{105}$ An "of" royalty interest varies with the size of the landowner's royalty in leases. ${ }^{106}$ As demonstrated in the cases discussed below, these disputes arise when the royalty in a new lease

104. See, e.g., 2 Williams \& MeYers, supra note 103, § 327.3, at 94.1; Phillip E. Norvell, Pitfalls in Developing Lands Burdened by Non-Participating Royalty: Calculating the Royalty Share and Coexisting with the Duty Owed to the Non-Participating Royalty Owner by the Executive, 48 ARK. L. REV. 933, 951 (1995). The author approves of the "multiply" approach used by the Arkansas Supreme Court in Palmer v. Lide, in which the court held:

It will be seen that the deed refers not once but four times either to $1 / 8$ th of $1 / 8$ th of the royalty or to $1 / 8$ th of $1 / 8$ th of the royalty to be retained or reserved in any oil, gas, or mineral lease, leases, or contracts. It is not possible to interpret the unmistakably clear language of the deed to mean $1 / 8$ th of $1 / 8$ th of the total production, as the appellant would have us do.

567 S.W.2d 295, 296 (Ark. 1978). The author concludes that, "[o]ne cannot quarrel with the construction of the 'double fraction' formula by the Arkansas Supreme Court in Lide [sic] .... However, one is haunted by the fear that the 'horrors of the double fraction' may be the result of an error based simply on the parties' selection of the wrong royalty deed form." Norvell, supra note 104 at 951.

105. SMith \& WeAVER's TeXAS LAW OF OIL AND GAS, § 3.7, at 3-46 n.187.2.

106. See Range Res. Corp. v. Bradshaw, 266 S.W.3d 490, 493 (Tex. App. 2008) (comparing a fraction "of" royalty versus a "fractional" royalty and stating that a fraction "of" royalty " "floats in accordance with the size of the landowner's royalty contained in the lease"); see also WILLIAMS \& MEYERS, OIL AND GAS Law 327 (2012) [hereinafter WiLliams \& MEYERS]. There is an additional difference: the effect of the executive's duty to lease. With an "of" royalty, the executive could potentially breach the duty of "utmost good faith" by negotiating a landowner's royalty that was too low. See Bradshaw v. Steadfast Fin., LLC, 395 S.W.3d 348, 364-65 (Tex. App. 2013). If the royalty interest is fixed, however, the negotiated royalty cannot affect the "fixed" owner's share of production. See id. (discussing cases in which the executive breached the duty of utmost good faith by entering into a lease depriving the royalty owner of benefits they would have received in a lease to a disinterested party). 
departs from the traditional 1/8 landowner's royalty.

Hudspeth v. Berry, ${ }^{107}$ a 2010 opinion, involved a dispute over a 1943 deed reserving an "undivided 1/40th royalty interest (being 1/5th of $1 / 8$ th)" with grantee reserving leasing rights, and the grantor receiving $1 / 5$ of the usual $1 / 8$ royalty. ${ }^{108}$ The Berrys owned the reserved interest and claimed their predecessors were each entitled to $1 / 5$ of the $1 / 5$ landowner's royalty reserved in a new lease, or $1 / 25$ of the proceeds from production. ${ }^{109}$ As a result, the Berrys claimed entitlement to a total of $2 / 25$ of the production proceeds. ${ }^{110}$ The trial court agreed with the Berrys' interpretation. ${ }^{111}$ The court of appeals, however, held the deed reserved two fixed 1/40 royalty interests, a ruling the Berrys did not appeal to the Texas Supreme Court. ${ }^{112}$

However, an opinion decided two years before Berry addressed a deed with similar language, including an express reference to a royalty the size "of" the usual 1/8 lease royalty. The deed in that case, Range Resources Corp. v. Bradshaw ${ }^{113}$ reserved:

an undivided one-half (1/2) Royalty (Being equal to not less than an undivided one-sixteent[h] (1/16)[)] of all the oil, gas and/or other minerals ... to be paid or delivered to said Grantors ... free of cost Forever.... In the event oil, gas or other minerals are produced... Grantors ... shall receive not less than one-sixteenth (1/16) portion (being equal to one-half (1/2) of the customary one-eighth (1/8) Royalty)....

Both the trial court and the court of appeals interpreted the reservation as a fraction "of" royalty rather than as a "fixed" fractional royalty. ${ }^{115}$ The appellate court opinion contains an extensive discussion of the difference between the two types of interests and reviews a 1980 Texas Supreme Court case involving a reservation that raised the "restated" fraction problem. ${ }^{116}$ In that case, Brown v. Havard, the majority concluded that the deed was ambiguous, but the dissent viewed

\footnotetext{
107. No. 2-09-225-CV, 2010 WL 2813408 (Tex. App. July 15, 2010). In the interest of full disclosure: I provided an expert opinion in support of Berry's position.

108. Id. at $* 2$.

109. Id. at *1.

110. Id.

111. Id

112. Id. at $* 4$.

113. Range Res. Corp. v. Bradshaw, 266 S.W.3d 490 (Tex. App. 2008).

114. Id. at 493-94 (emphasis added).

115. Id. at 497.

116. See id. at 493-97 (discussing Brown v. Havard, 593 S.W.2d 939 (Tex. 1980)).
} 
the deed as having unambiguously created a fraction "of" royalty. ${ }^{117}$ In Range Resources, the court addressed differences between the two deeds, but ultimately favored the dissent's approach in Brown. ${ }^{118}$ The losing party in Range Resources asked the Texas Supreme Court to review the appellate court decision, but the court declined its petition. ${ }^{119}$

A case decided in 2011 appears consistent with Range Resources rather than Berry. In Sundance Minerals v. Moore, a deed reserved "an undivided and non-participating one-half interest in the oil, gas and other mineral rights" or "one half of the usual one eighth royalty received forsuch [sic] oil, gas and other minerals produced ...."120 The court held the deed reserved $1 / 2$ "of" the $1 / 5$ landowner's royalty in the subsequent lease. ${ }^{121}$

Although the result in Sundance Minerals reflects the analysis approach, that opinion, like the Range Resources opinion, does not overtly address the estate misconception or the legacy of the 1/8 royalty. However, in reaching their conclusions both opinions cite extensively to Luckel v. White and follow its harmonizing approach. ${ }^{122}$ That 1991 Texas Supreme Court opinion, in which the court interpreted a deed with the conflicting fractions $1 / 4$ and $1 / 32$, expressly acknowledges the effect of the $1 / 8$ royalty on drafting:

117. 593 S.W.2d 939, 942, 945 (McGee, J., dissenting).

118. Range Res. Corp., 266 S.W.3d at 495-96. The initial dispute in Range Resources was whether the executive had breached its duty to the royalty owner by entering into a lease with only a $1 / 8$ landowner's royalty. Id. at 492 . That duty, however, has no application to a "fixed" royalty interest since leasing cannot affect the share owed to those interest owners. See id. at 493 . The duty applies when the interest is a fraction "of" the lease royalty, since the executive must exercise leasing decisions according to an "utmost good faith" standard. See Bradshaw v. Steadfast Fin., LLC, 395 S.W.3d 348, 370 (Tex. App. 2013) (noting that when the interest is a fraction "of" the lease royalty, the executive has more control and, therefore, is under an elevated duty). In Range Resources, the royalty owner claimed the executive could have negotiated for $1 / 4$ landowner's royalty in the lease. 266 S.W.3d at 492. The executive's duty is addressed below (Lesley discussion). See infra Part V.

119. Petition for Review of Range Resources Corporation and Range Production I, L.P., Range Res. Corp. v. Bradshaw (Tex. Dec. 28, 2008) (No. 08-0949) (pet. denied), available at http://www.supreme.courts.state.tx.us/ebriefs/08/08094901.pdf.

120. 354 S.W.3d 507, 510 (Tex. App. 2011) (emphasis added).

121. Id. at 512-13 (affirming trial court's grant of summary judgment interpreting that the deed reserved $1 / 2$ of the $1 / 5$ royalty).

122. See, e.g., Range Res. Corp., 266 S.W.3d at 496 ("Construing the deeds as a whole, and harmonizing all parts to give effect to the parties' intent, we determine that a 'fraction of royalty' was conveyed."); Sundance Minerals v. Moore, 354 S.W.3d 507, 511 (Tex. App. 2011) (“All parts of the deed are to be harmonized, construing the instrument to give effect to all of its provisions."). 
We do not quarrel with the assumption that the parties probably contemplated nothing other than the usual one-eighth royalty. But that assumption does not lead to the conclusion that the parties intended only a fixed $1 / 32$ nd interest. It is just as logical to conclude that the parties intended to convey one-fourth of all reserved royalty, and that the reference to $1 / 32$ nd in the first three clauses is "harmonized" because one-fourth of the usual one-eighth royalty is $1 / 32 \mathrm{nd}$.

As in Range Resources, the losing party in Sundance Minerals petitioned the Texas Supreme Court to review the appellate court's ruling. That petition stressed the surge of shale production in Texas and the decline of the usual 1/8 landowner's royalty, and asked the court to provide guidance:

Practitioners and lower courts dealing with the resurgence of cases need guidance on significant, recurring issues like the deed construction dispute presented in this petition for review. Especially when language in deeds use differing fractions to express the intent of the parties regarding the character and size of the interest reserved, it is vitally important that all of the reviewing courts consistently apply the rules of interpretation and follow established precedent to reach the same results.

Despite this plea for guidance, the Texas Supreme Court declined to review the court of appeals' decision in Sundance Minerals. The court also denied a petition for review in another appellate opinion from 2012, Coghill v. Griffith. ${ }^{125}$ That opinion relies heavily on Luckel and cites Range Resources in concluding that a deed with restated and double fractions created an "of" royalty interest. ${ }^{126}$

However, another recent opinion retreats to the "multiply" approach. In Moore v. Noble Energy, the court viewed the following language as creating a fixed 1/16 royalty interest: "a one-half non-participating royalty interest (one-half of one-eighth of production)." 127 In that

123. Luckel v. White, 819 S.W.2d 459, 462 (Tex. 1991).

124. Petition for Review of Sundance Minerals, L.P., at vii, Sundance Minerals, L.P. v. Moore, 354 S.W.3d 507 (Tex. 2012) (No. 02-10-00403-CV) (pet. denied), available at http://www.supreme.courts.state.tx.us/ebriefs/12/12007801.pdf.

125. Petition for Review of Coghill v. Griffith, 358 S.W.3d 834 (Tex. App. 2012) (No.12-0170) (pet. denied), available at (http://data.scotxblog.com/scotx/no/12-0170.

126. Id. at 838-40 ("The language used in Range Resources Corp. and in the instant case establishes that the interest reserved was a fraction of royalty and not a fractional royalty."). The deed's language stated, "the Grantor reserves and excepts unto himself . . . an undivided one-eighth $(1 / 8)$ of all royalties payable under the terms of said lease, as well as an undivided one-eighth (1/8) of the usual one-eighth $(1 / 8)$ royalties provided for in any future" lease. Id. at 836.

127. 374 S.W.3d 644, 645 (Tex. App. 2012) (emphasis added). 
opinion, the court relies heavily on the Williams \& Meyers treatise, which approves of multiplying rather than analyzing double fractions, and attempts, unsatisfactorily, to distinguish Range Resources. ${ }^{128}$

Another recent appellate court opinion also strains to distinguish Range Resources and Sundance Minerals and, like the Moore opinion, retreats to the multiply approach. ${ }^{129}$ Wynne/Jackson Development $v$. PAC Holdings, Ltd., involves Barnett shale production from property in Denton County, Texas. ${ }^{130}$ The relevant language provided that the grantor reserved:

a non-participating royalty of one-half $(1 / 2)$ of the usual one-eighth $(1 / 8)$ royalty in and to all oil, gas, and other materials produced, saved and sold from the above-described property, provided, however, that although said reserved royalty is non-participating and Grantee shall own and possess all leasing rights in and to all oil, gas and other minerals, Grantor shall, nevertheless, have the right to receive one-half $(1 / 2)$ of any bonus, overriding royalty interest, or other payments, similar or dissimilar, payable under the terms of any oil, gas and mineral lease covering the above-described property.

The parties framed the issue as whether the deed reserved a fixed or fraction "of" royalty. ${ }^{132}$ In reversing the trial court and holding the deed reserved a fixed fractional royalty, the court relied on cases, such as a

128. See id. at 647-51. The court also relied on Brown v. Havard, 593 S.W.2d 939 (Tex. 1980). In Brown, a deed reserved "an undivided one-half non-participating royalty (being equal to, not less than an undivided 1/16th)...." Id. at 940. The majority opinion determined the deed was ambiguous and returned the case to the trial court. Id. at 944. A dissenting opinion, however, argued that the deed was unambiguous and conveyed a 1/2 "of" royalty. Id. at 945 (McGee, J., dissenting).

129. Wynne/Jackson Dev., L.P. v. PAC Capital Holdings, Ltd., No. 13-12-00449-CV, 2013 WL 2470898, at*3 (Tex. App. June 6, 2013).

130. Id. at $* 1$.

131. Id. at $* 4$.

132. The appellate opinion does not suggest that the deed reserved an undivided $1 / 2$ nonexecutive mineral interest, perhaps in light of the "non-participating royalty" label. $I$ d. at *4-5. The owner of an undivided $1 / 2$ mineral interest is entitled to $1 / 2$ of the royalty, as explained above. See supra Part II.C.1. However, under the French redundancy approach, which focuses on express references to other mineral estate attributes, that may have been a viable argument. See id. at*3 (comparing the attributes of the mineral estate owned by a mineral fee owner with those of a nonparticipating royalty owner). Here, the grantor reserved a royalty plus the right to receive bonus payments, a mineral-estate attribute. Id. at *4; see also Altman v. Blake, 712 S.W.2d 117, 120 (Tex. 1986) (finding that the deed, which stripped some mineral-estate attributes, created a non-executive mineral interest rather than royalty interest). The Altman deed, however, did not expressly label the interest a "non-participating royalty interest." Id. at 118 (referring instead to a non-participating mineral interest). 
1955 Texas Supreme Court decision, that multiplied, rather than analyzed, double fractions. ${ }^{133}$ In other words, unlike Range Resources and Sundance Minerals, the Wynne/Jackson decision ignores the legacy of the usual 1/8 landowner's royalty, despite the express reference to that royalty in the deed.

2. Lessons from the Double and Restated Fraction Cases for the Shale Era

The results reached in Sundance Minerals, Range Resources, and Coghill reflect the analysis approach for double and restated fractions. ${ }^{134}$ That approach respects the goal of deed interpretation, which is to ascertain the intent of the parties. The analysis approach also promotes title stability by seeking intent from the four corners of the deeds, without resorting to outside evidence. Sundance Minerals, Range Resources, and Coghill reach results consistent with language within the deeds. Specifically, the deeds in each of those cases mention the "usual $1 / 8$ lease royalty" and describe the interest at issue as a fraction "of" that royalty. ${ }^{135}$ By noting those provisions and relying on Luckel's "harmonizing" approach, those opinions incorporate the legacy of that once-common royalty on drafting into the interpretative process.

The Berry, Moore, and Wynne/Jackson opinions, on the other hand, ignore express references to the "usual $1 / 8$ royalty" and other language, including the reference to a $1 / 5$ interest in Berry and a $1 / 2$ interest in

133. The court cited Harriss v. Ritter, a case which held that the double fractions " one-half of one-eighth . . could have but one meaning and that is $1 / 16$ th of the royalty ...." Wynne/Jackson, 2013 WL 2470898, at *4 (quoting Harriss v. Ritter, 279 S.W.2d 845, 847 (Tex. 1955)).

134. Sundance Minerals v. Moore, 354 S.W.3d 507, 511-13 (Tex. App. 2011) (employing only "the express language found within the four corners of [the deed]" to determine the interested the parties intended to convey); Range Res. Corp. v. Bradshaw, 266 S.W.3d 490, 493, 496-97 (Tex. App. 2008) (looking exclusively to "the objective intent expressed or apparent in the writing" to determine the royalty conveyed); Coghill v. Griffith, 358 S.W.3d 834, 836-40 (Tex. App. 2012) (also using the four corners rule to determine the parties intended to grant a fraction of royalty). Another recent case, which is not reported, expressly endorses the analysis approach and consideration of the "estate misconception." See Hernandez v. El Paso Prod. Co., No. 13-09-184CV, 2011 WL 1442991, at*4 (Tex. App. Apr. 14, 2011) (citing Laura H. Burney, The Regrettable Rebirth of the Two-Grant Doctrine in Texas Deed Construction, 34 S. TEX. L. REV. 73, 86 (1993)).

135. See, e.g., Sundance Minerals, 354 S.W.3d at 511-12 (finding that the grantor meant to reserve "one half of the usual one eighth" royalty); Range Res. Corp., 266 S.W.3d, at 493 (noting the problems the estate misconception played in deed construction); Coghill, 358 S.W.3d at 838-39 (harmonizing the differing fractions in the deed in light of the usual 1/8 royalty). 
Moore and Wynne/Jackson. ${ }^{136}$ Further departing from the four-corners rule, the Moore and Wynne/Jackson opinions insert language not found in the document - the fraction $1 / 16 .^{137}$ In short, these three decisions merely multiply and fail to analyze the language in the deeds.

For future drafting, the decisions discussed above and others teach these lessons: drafters should state expressly whether they intend to convey or reserve a "fixed fractional interest" rather than a fraction "of" the royalty reserved in existing and any future leases. An additional statement should expressly clarify that, for instance, a fraction is not a "fixed" interest, if an "of" royalty interest is intended. And the size of that "fraction "of' royalty" or "fixed royalty" should be stated as a single rather than a double fraction.

However, as a Texas court noted in Barker v. Levy when reviewing drafting advice regarding the "mineral or royalty" issue, discussed below, "It is quite probable that these [parties] now heartily agree with this advice. However, it was written [decades] too late to have been helpful" in the shale era. ${ }^{138}$ Title examiners could view the Texas Supreme Court's decisions declining petitions for review in Sundance Minerals, Range Resources and Coghill as approval of those betterreasoned opinions. ${ }^{139}$ The Texas Supreme Court's opinions in Luckel and Concord Oil also support the approach in those three cases by

136. Hudspeth v. Berry, No. 2-09-225-CV, 2010 WL 2813408, at *1 (Tex. App. July 15, 2010) (interpreting the deed as granting two fixed royalty interest instead of the " $1 / 5$ th of $1 / 8$ th" royalty); Moore v. Noble Energy, Inc., 374 S.W. 3d 644, 651 (Tex. App. 2012) (interpreting the deed to "reserve a royalty of one-half of one-eighth of production, or one-sixteenth"); Wynne/Jackson, 2013 WL 2470898, at *1-2,*5 (Tex. App. June 6, 2013) (finding that the interest conveyed was a fractional royalty, not a fraction of royalty and entitled Wynne/Jackson to one sixteenth of production instead of $1 / 2$ of the usual $1 / 8$ royalty).

137. See Moore, 374 S.W.3d at 647-48 (Tex. App. 2012) (relying on MARTin \& Kramer, supra note 35, to insert language into the deed). The Moore opinion also diverts to another troubled interpretative trail: the court views the lack of a producing well at the time the deed was drafted as relevant to interpreting the deed. Id. at 651 . However, as discussed in the next section, allowing such extraneous facts to affect the interpretative process detracts from title stability. See infra discussion Part III.B.1.b. (analyzing Oklahoma approach, which allows the term "royalty" to change depending on existence of lease at time of drafting). See also Wynne/Jackson, 2013 WL 2470898, at $* 1-2, * 5$ (interpreting deed language describing a "“one-half $(1 / 2)$ of the usual one-eighth $(1 / 8)$ royalty in and to all oil, gas and minerals, produced, saved and sold from [such property]" as granting a fixed royalty of $1 / 16$ of the production).

138. Barker v. Levy, 507 S.W.2d 613, 618 (Tex. Civ. App. 1974).

139. The same reasoning would apply to the Texas Supreme Court's decision not to accept petitions for the multiclause deed cases, Garza and Hausser. But see TEX. R. APP. P. 56.1 (noting that petitions denied do not carry the same precedential value as petitions refused, which are viewed as Supreme Court opinions). 
acknowledging the legacy of the $1 / 8$ royalty. ${ }^{140}$ Absent firmer endorsement from the state's high court, however, these mixed opinions may motivate parties to file lawsuits over deeds with double and restated fractions in the shale era.

\section{THE “MiNERAL OR ROYALTY” QUESTION}

As noted above, in addition to the decision about the size of the fractional interest a grantor intends to create, drafters must decide whether to create a mineral or royalty interest. In fact, several of the fractional-interest cases discussed above also involved this second inquiry. ${ }^{141}$ This section examines the drafting advice provided in Barker, which encourages the use of the "mineral" or "royalty" labels, and contributes additional statements for distinguishing between the two. ${ }^{142}$

\section{A. The Value of the "Mineral" or "Royalty" Label in Drafting and Interpreting Deeds}

Although the Barker advice appears in a 1974 case and quotes from a 1958 article, its suggestion to use mineral and royalty labels has merit today. ${ }^{143}$ However, in order to pick a label, drafters must engage in two prior steps in the decision-making process. First, drafters should examine the differences between mineral and royalty interests; and, second, they should decide which type they prefer to create. However, as noted in Barker, this drafting advice comes too late for title examiners today faced with interpreting decades-old deeds. ${ }^{144}$ Complicating the interpretative process, decades of decisions from different states provide

140. See Luckel v. White, 819 S.W.2d 459, 462 (Tex. 1991) (discussing the "usual one-eighth royalty"); Concord Oil Co. v. Pennzoil Exploration \& Prod. Co., 966 S.W.2d 451, 459 (Tex. 1998) (noting that the prevailing royalty in private oil and gas leases was a 1/8 royalty during the Era in which the Concord deed was executed).

141. Hausser v. Cuellar, 345 S.W.3d 462, 468 (Tex. App. 2011) (noting that "after determining both deeds conveyed a mineral interest as opposed to a royalty interest, [the court] addressed the issue of the conflicting fractions"); Garza v. Prolithic Energy Co., 195 S.W.3d 137, 142 (Tex. App. 2006) (deciding first that "the deeds conveyed a mineral interest" before addressing the conflicting fractions).

142. Barker v. Levy, 507 S.W.2d 613, 618 (Tex. Civ. App. 1974).

143. Id. (quoting Emery, Conveyancing of Interests in Oil and Gas, 29 Okla. B.J. 1965 (1958)) (advising that deeds conveying royalties should contain language stating " it is the intention of the parties hereto to convey a royalty interest as distinguished from a mineral interest"').

144. Id. (noting, in particular, that Emery's drafting advice came "twenty-eight years too late to have been helpful" in interpreting the Barker deed). 
differing advice about the appropriate language for creating each type of interest. This section reviews the differences between mineral and royalty interests and the value of these labels in the interpretative process.

1. The Difference between Mineral and Royalty Interests: The Bundle of Sticks

Theoretically, drafters in the shale era should understand the differences between mineral and royalty interests. Courts articulate those differences by analogizing to the classic property law concept, "the bundle of sticks." 145 Specifically, the sticks in the mineral-estate bundle consist of the following: "(1) the right to develop (the right of ingress and egress), (2) the right to lease (the executive right), (3) the right to receive bonus payments, (4) the right to receive delay rentals, [and] (5) the right to receive [landowner's] royalty payments." 146 Stated differently, a mineral interest is a cost-bearing interest that entitles the owner to a proportionate share of lease benefits, including bonus, rentals, and landowner's royalty.

A royalty interest, on the other hand, is a non-cost bearing interest devoid of the mineral-estate sticks, except the right to share in proceeds from the sale of production. ${ }^{147}$ In other words, a "royalty" is non-cost bearing and non-participating interest, meaning the owner cannot execute leases or develop the property. When an owner creates a royalty interest by deed or reservation, the label "non-participating royalty interest" applies, which distinguishes that interest from mineral interests and from the royalty reserved in the lease. ${ }^{148}$

145. See, e.g., Lesley v. Veterans Land Bd. of Tex., 352 S.W.3d 479, 480-81 (Tex. 2011) (stating that the "right to lease minerals - the executive right-is one 'stick' in the bundle of five real property rights that comprise a mineral estate"). Courts and commentators also refer to the "sticks" that comprise a mineral interest as the incidents or attributes of the mineral estate. See, e.g., Altman v. Blake, 712 S.W.2d 117, 118 (Tex. 1986) (listing the "five essential attributes of a severed mineral estate"); Hamilton v. Morris Resources, Ltd., 225 S.W.3d 336, 344 (Tex. App. 2007). See generally Williams \& MEYERS, supra note 106, §202.2. Pennsylvania is a major shale-era state with relatively little case law for resolving shale era disputes, including the "magic words" for creating mineral and royalty interests. Id.; see also infra Part IV.A (examining the effect of old Pennsylvania precedent on the meaning of "minerals").

146. Altman, 712 S.W.2d at 118.

147. See MARTIN \& KRAMER, supra note 35, at 964 (noting the characteristics of a royalty interest).

148. See id. at 698 (noting the characteristics of a non-participating royalty interest); Hamilton, 225 S.W.3d at 344 (defining the properties of a non-participating royalty interest). 
2. The Nonparticipating Royalty Interest vs. Mineral Interest

(Participating and Non-Executive): The Well-Drafted Form in the

Shale Era

Proceeding with the ideal pre-drafting decision-making process, after reviewing the differences between a royalty and mineral interest, Owner would consider additional questions. Does Owner intend for Grantee to have the right to execute leases and share in lease benefits? Or does Owner prefer to create an non-participating royalty interest that may simply someday entitle Grantee to a share of production? Additional questions include whether Owner prefers to maintain all leasing rights in the property, even if he intends to convey a mineral interest, which is a viable option because the "sticks" in the mineral estate bundle are severable. Indeed, as discussed below, Owners often sever the executive right and create non-executive or non-participating mineral interests. ${ }^{149}$ In those instances, Owner maintains the right to lease the entire mineral estate, but Grantee shares proportionately in lease benefits, such as rents and royalties. ${ }^{150}$

Assuming Owner has proceeded through this process and selected the interest he intends to create, the next question is which language should Owner insert in the deed? At this point, the advice suggested in Barker warrants repeating: "good draftsmanship requires that where a conveyance of a royalty is intended, [t] here should be added the proviso that 'it is the intention of the parties hereto to convey a royalty interest as distinguished from a mineral interest.",151

Fortunately, many deed forms today embrace that advice and consistently adopt the mineral or royalty labels. Non-participating royalty is now an industry-accepted term. ${ }^{152}$ Additionally, well-drafted forms include other phrases endorsed in case law for creating mineral versus royalty interests. For example, courts have equated the phrase "in and under" with the creation of a mineral interest and that phrase appears

\footnotetext{
149. See infra Part V.D.

150. Altman, 712 S.W.2d at 118-20 (noting that the deed reserved the rights to lease and receive royalty to the grantor but that the grantees were entitled to a fraction of the royalty reserved under the lease).

151. Barker v. Levy, 507 S.W.2d 613, 618 (Tex. Civ. App. 1974) (internal citation omitted).

152. The deed form in this case clearly created a non-participating royalty interest and avoided the "mineral or royalty" question. See 11 Tex. Prac., Texas Methods of Practice $§ 16: 21$ (3d ed. 2013) (form for nonparticipating royalty interest deed).
} 
in mineral deed forms. ${ }^{153}$ Ideally, forms today avoid contradictory terms, such as combining the royalty label with an express grant of "ingress and egress," a stick in the mineral estate bundle. ${ }^{154}$ As discussed below, however, drafters of new deeds should check whether forms reflect the dictates of case law. The next section examines precedent affecting the mineral or royalty question.

\section{B. The "Precedent Problem" and the "Mineral or Royalty" Question in the Shale Era}

\section{The Texas v. Oklahoma Approaches}

Although title examiners prefer to encounter the ideal forms described above, courthouses across the country contain countless deeds with contradictory and confusing terms. Litigation over the interpretation of those deeds has produced often misguided opinions, creating a precedent problem for title examiners and courts in the shale era. In many disputes, courts accord great weight to the royalty label in the deed interpretation process. ${ }^{155}$ However, to understate the problem, if "the word 'royalty' is coupled with other terms, the result is not always clear." 156 Additionally, other jurisdictions, notably Oklahoma, allow the meaning of royalty to change depending on whether a lease was outstanding on the property. ${ }^{157}$

\section{a. Texas}

Writers often note that other states look to Texas law for guidance in resolving oil and gas disputes. ${ }^{158}$ Indeed, as the nation's second largest

153. See, e.g., 6 William B. Burford, West's TeXas Forms: Minerals, OIl \& Gas $§ 1: 3$ (4th ed. 2012) (form using "in and under" to create a mineral interest).

154. See 2 WILLIAMS \& MEYERS, supra note 103, § 304.2-4.8 (describing the various phrases that are associated with a royalty interest).

155. See generally HemingWay et Al., OIL AND Gas LaW AND TaXATION 80 (4th ed. 2004) (noting that in many jurisdictions, "the presence of the term 'royalty' may convert what is otherwise a mineral interest to one of royalty only").

156. Id

157. See infra note 178 and accompanying text.

158. Kurth, supra note 4, 4-1 at \$4.09; Rebecca W. Watson, Hydraulic Fracturing as a Subsurface Trespass: Will Texas Precedent Lead the Way, 49 Rocky MTN Min. L. Found. J. 235, 235 (2012). Not all states decide to follow Texas's lead on resolving oil and gas disputes. See, e.g., Garman v. Conoco, Inc., 886 P.2d 652, 657, 660 (Colo. 1994) (noting Texas approach charging landowner with share of post-production costs under market value royalty provision and rejecting it). 
state with a long and strong production history from millions of primarily private acres of land, Texas has produced volumes of case law on a variety of issues. Historically, dozens of Texas decisions have addressed the mineral or royalty inquiry. ${ }^{159}$ However, the Texas Supreme Court last addressed that question in two cases from the 1990s, French $v$. Chevron U.S.A., Inc. ${ }^{160}$ in 1995 and Temple-Inland Forest Products Corp. v. Henderson Family Partnership ${ }^{161}$ in 1997. The deeds at issue in those cases presented the problem of the "royalty" label mixed with mineral terms. The French deed was titled "mineral deed."162 Yet titles of documents carry little weight in the interpretative process. ${ }^{163}$ However, the deed also included the mineral phrase, "in, under and that may be produced from...."164 The confusion arose in a second paragraph, which expressly stated that the "conveyance is a royalty interest only," and continued to strip from the conveyance all of the sticks in the mineral estate bundle, except the right to receive a fixed fractional share of production. ${ }^{165}$ That fixed fraction, which appeared in the granting clause, was stated as "being an undivided 1/656.17th" interest. $^{166}$

The parties disputed whether the deed conveyed a mineral interest or a fixed fractional royalty interest. ${ }^{167}$ The difference in monetary terms was significant: if the deed conveyed a fixed fractional royalty, the grantee's successor-in-interest was entitled to that fixed share of the proceeds from the sale of the production. ${ }^{168}$ On the other hand, if the

159. Dozens of articles and treatises have also addressed the issue. See, e.g., HEMINGWAY, supra note 155, at 80-81 (discussing the role of a deed's language in determining whether a mineral or royalty interest has been conveyed); Burney, Interpreting Mineral and Royalty Deeds, supra note 8, at 2. See generally Richard C. Maxwell, Mineral or Royalty-The French Percentage, 49 SMU L. REV. 543 (1996).

160. 896 S.W.2d 795 (Tex. 1995).

161. 958 S.W.2d 183 (Tex. 1997).

162. French, 896 S.W.2d at 796.

163. Williams \& MEYERS, supra note 106, at $§ 304.1$, at 467-68) ("The title of the instrument is never given conclusive effect in the construction process and rarely, if ever, has paramount importance.").

164. French, 896 S.W.2d at 796 .

165. Id.

166. Id. The granting clause also described the interests as "an undivided Fifty (50) acre interest," a fact that the court pointed to in reaching its conclusion that the deed created a mineral interest. Id. at 797-98.

167. Id. at 796 .

168. Id. (noting that the grantee's successor maintained that "the deed conveyed a pure fixed royalty interest ... [in] production"). 
deed conveyed only a $1 / 656.17$ fractional mineral interest, the grantee's cost-bearing interest must be multiplied by the $1 / 8$ landowner's royalty in the lease, meaning the owner received $1 / 5248$ of the proceeds. ${ }^{169}$

The Texas Supreme Court held the deed conveyed a mineral interest. ${ }^{170}$ In reaching its conclusion, the court applied what critics labeled a redundancy approach. ${ }^{171}$ According to the court, the interest described was not a royalty interest because the express language removing the attributes of the mineral estate "would serve no purpose whatsoever if the interests in minerals being conveyed was a 1/656.17 royalty interest, that is, 1/656.17 of all production." 172

For drafting after 1995, French taught these lessons: if Owner intends to convey a royalty interest, use that term, avoid contradictory mineral phrases, such as "in and under," and omit any reference to the attributes of the mineral estate. ${ }^{173}$ As always, however, such advice comes too late for title examiners faced with determining the meaning of existing deeds. Fortunately, the Texas Supreme Court revisited French two years later in Temple-Inland and produced an opinion that assuaged the concerns of critics, who viewed French as having incorrectly ignored the "royalty" label in the interpretation process. ${ }^{174}$

The Temple-Inland deed involved a reservation of a $1 / 16$ interest. ${ }^{175}$

169. Burney, Oil, Gas \& Mineral Conveyances, supra note 10, at 7.

170. French, 896 S.W.2d at 798.

171. Burney, Interpreting Mineral and Royalty Deeds, supra note 8, at 34 (citing David E. Pierce, Developments in Nonregulatory Oil and Gas Law: The Continuing Search for Analytical Foundations, 47 InST. ON OIL \& GAS L. \& TAX'N 1-1, 1-18 (1996)).

172. French, 896 S.W.2d at 798.

173. One writer suggests using the royalty label multiple times. See Terry Cross, Why Texas Titles are Different, 4 Rocky MTN. MiN. L. FOUND. 16 (2007) (“Temple-Inland opinion awards cumulative points for repeating a key word six times. If saying the same thing over six times adds certainty in this treacherous area, who can afford not to do it? Simply saying, "this conveyance is a royalty interest' only once was insufficient to create a royalty interest under French v. Chevron." (citing Temple-Inland Forest Prods. Corp. v. Henderson Family P'shp, Ltd., 958 S.W.2d 183, 186 (Tex. 1997))).

174. See Burney, Interpreting Mineral and Royalty Deeds, supra note 8, at 34 (opining that the French court ignored prior case law that had given weight to the royalty label and instead should have viewed the language removing the mineral-estate attributes as affirming the royalty label).

175. 958 S.W.2d at 184. The issue in the case was whether a deed had reserved a mineral or a royalty interest. $I d$. at 183-84. An unanswered question from the opinion is why the deed expressly conveyed a 15/16 mineral interest. Id. at 184 . In other words, who is the owner of the other $1 / 16$ mineral interest? The appellate court had focused on this fact in holding that the deed must have reserved a 1/16 mineral interest. Temple-Inland Forest Products Corp. v. Henderson Family P'ship, Ltd., 911 S.W.2d 531, 534 (Tex. App. 1995) (discussing what percentage of the mineral interest was retained), rev'd, 958 S.W.2d 183 (Tex. 1997); see also Burney, Interpreting Mineral and Royalty 
As in French, initial language in the reservation reflected a mineral interest. However, the deed continued to repeatedly describe the interest as "royalty," and specifically described it as non-cost bearing. ${ }^{176}$ Although the court did not overrule French, it effectively limited it to its facts. ${ }^{177}$ Therefore, in future disputes, one could infer that the royalty label should carry weight in the interpretative process. However, the Texas Supreme Court focused on the particular language in the TempleInland deed, and avoided sweeping statements about the value of the royalty label in general. ${ }^{178}$ Therefore, parties whose rights depend on deeds with mixed mineral and royalty terms will remain motivated to litigate in the shale era.

\section{b. Oklahoma}

In resolving the mineral or royalty question, Texas courts have properly not considered whether a lease existed on the property at the time the deed was executed. ${ }^{179}$ Unfortunately, that approach has been adopted in some jurisdictions, notably Oklahoma:

The Oklahoma courts have been consistent in following the approach that the existence of a lease on the property at the time of execution of a

Deeds, supra note 8, at 42-43 (noting that the Supreme Court did not answer the obvious question of who owned the $1 / 16$ mineral interest).

176. Temple-Inland, 958 S.W.2d at 184.

177. Burney, Interpreting Mineral and Royalty Deeds, supra note 8, at 41. In particular, the court addressed the French opinion's approach to Watkins v. Slaughter. Temple-Inland, 958 S.W.2d at 185. The French opinion viewed Watkins as requiring not only the term "royalty" but also the additional phrase from "actual production." French, 896 S.W.2d at 797. The Temple-Inland opinion clarified that the "'royalty' label—without the phrase 'from actual production'—is a reliable indicator of intent when interpreting and drafting deeds." Burney, Interpreting Mineral and Royalty Deeds, supra note 8, at 42; see also Temple-Inland, 958 S.W.2d at 186 (distinguishing the language from French that the words "royalty from actual production" are not required). However, a recent Texas case relied on the "redundancy analysis" from French to hold a multiclause deed form conveyed a stripped mineral interest. Garza v. Prolithic Energy Co., 195 S.W.3d 137, 142 (Tex. App. 2006). "Furthermore, the reservation of the [mineral estate attributes] would have been redundant if the deeds intended to convey a royalty interest. Therefore ... we hold that the deeds conveyed a mineral interest." Id.

178. Temple-Inland, 958 S.W.2d at 184-85.

179. In some Texas opinions, however, courts appear to be influenced by whether or not a lease was on the property. See Moore v. Noble Energy, Inc., 374 S.W.3d 644, 647 (Tex. App. 2012) ("The centerpiece of the Moores' argument is the contention that the deed reasonably can be construed to reserve a royalty of one-half the royalty retained by the lessor in a future lease."). But see Barker v. Levy, 507 S.W.2d 613, 617 (Tex. Civ. App. 1974) ("[T] Texas law that a lease be in effect before a royalty interest can be created."). 
deed indicates an intent that a royalty interest was created, and that the word 'royalty' in those cases should be construed in a narrow sense. Where no lease was outstanding at the time, the broader construction of mineral interest has been applied.

Scholars have consistently criticized the Oklahoma approach for creating title uncertainty and drafting problems:

The average lawyer often has difficulty in understanding the difference between a royalty and a mineral interest. The Oklahoma cases further complicate such a lawyer's task by requiring him or her to determine which of several meanings a term may have. The inevitable result has been litigation and a small, highly specialized bar.

\section{c. Drafting Lessons from the Texas and Oklahoma Approaches}

In the shale era, drafters should accord the terms "mineral" and "royalty" set meanings that reflect the bundle of sticks concept. Texas courts have, for the most part, endorsed that approach, which provides predictability for title examiners. Texas courts also ensure predictability and title certainty by resolving the mineral or royalty question from the four corners of the document as a matter of law. On the contrary, the Oklahoma cases have concluded the deeds were ambiguous, which requires factual determinations regarding the presence or absence of a lease in the trial court before meaning can be assigned to a deed. ${ }^{182}$

In response to the Oklahoma cases, drafters in that state should heed the Barker advice and add a sentence clarifying that a royalty interest, not a mineral interest, is intended, regardless of the presence or absence of a lease. ${ }^{183}$ For title examiners, owners and courts, however, the Oklahoma approach will continue to affect deed interpretation cases in the shale era, in that state and possibly others. A recent North Dakota case provides an example. In Hamilton v. Woll, the North Dakota

180. Hemingway, supra note 155, at 76 (quoting Richard Hemingway, Mineral-Royalty Distinction in Oklahoma, 52 Okla. B.J. 2791, 2795 (1981); see, e.g., Melton v. Sneed, 109 P.2d 509, 512-13 (Okla. 1940) (holding the deed ambiguous and establishing a rule of construction that a royalty term creates a mineral interest if no reference appears in the deed to any lease). Other jurisdictions may focus on the presence or absence of a lease, for varying reasons. See generally HEMINGWAY, supra note 155, at 72-78 (discussing approaches used in West Virginia, Colorado and other jurisdictions).

181. HemingWay, supra note 155 , at 77.

182. See, e.g., Melton, 109 P.2d at 512-13 (noting the impact of the presence of a lease on the construction of royalties).

183. Barker, 507 S.W.2d at 618. 
Supreme Court held fifteen 1950s deeds were ambiguous. ${ }^{184}$ The deeds contained mixed terms and other deeds executed by the grantor had previously been litigated. ${ }^{185}$ The proponent of the mineral interpretation pointed to the fact that the grantor "was from Oklahoma and during the time the 15 deeds were executed it was 'a matter of common knowledge' that 'the word [royalty] [wa]s frequently used in [Oklahoma] to denote an interest in the mineral rights." 186 While Hamilton may be limited to its facts, shale-producing states writing on cleaner precedent plates should avoid the Oklahoma path in favor of the Texas approach for resolving the mineral or royalty question. ${ }^{187}$

2. The Kansas Approach: Avoiding Non-Participating Royalty Interests and the Rule Against Perpetuities

While Oklahoma courts have focused on the presence or absence of an oil and gas lease in the mineral or royalty analysis, another fact plays a role in Kansas decisions: the need to avoid application of the common law rule against perpetuities. Under basic property law principles, the rule against perpetuities applies to non-vested interests, which are void if they fail to vest beyond the time frame allowed by the rule. ${ }^{188}$ Most states view the grant or reservation of a royalty interest (or nonparticipating royalty interest) as creating a vested property interest, whether or not the interest-owner ever receives royalty payments, thereby escaping the rule against perpetuities' application. ${ }^{189}$

184. 823 N.W.2d 754 (N.D. 2012)

185. Id. at 756 (noting that the deeds "were preprinted 'Mineral Deed' forms but stated ... that they conveyed undivided fractional 'Royalty' interests" and that similar deeds executed by the grantor Hamilton were found to be ambiguous in Williams Co. v. Hamilton) (citing Williams Co. v. Hamilton, 427 N.W.2d 822, 824 (N.D. 1988)).

186. Id. at 757 (citing Melton, 109 P.2d at 513).

187. See, e.g., Ray v. Luce, No. EQ 1989-15, 1990 WL 305162, at*584-85 (Pa. Ct. Com. Pl. Sept. 12, 1990) (relying on "sticks" in the bundle for resolving mineral or royalty issue).

188. Gray's classic definition of the rule against perpetuities is, "[n]o interest is good unless it must vest, if at all, not later than twenty-one years after some life in being at the creation of the interest.” John C. GRAy, The Rule Against PeRPEtuities § 201, at 191 (Roland Gray ed., 4th ed. 1942).

189. See Burney, A Pragmatic Approach, supra note 14, at 46 (citing Hanson v. Ware, 274 S.W.2d 359 (Ark. 1955); Gulf Refining Co. v. Stanford, 30 So.2d 516 (Miss. 1947); Schlittler v. Smith, 101 S.W.2d 543 (Tex. Comm'n App. 1937) (noting most jurisdictions have viewed nonparticipating royalty interest's as a vested interest). Other oil-patch interests raise rule against perpetuities issues, but courts generally avoid voiding the interest. Id. (discussing courts' creative approaches to avoid voiding reserved term interests). A poorly drafted document, however, could fall prey to the rule against perpetuities' effects. See Peveto v. Starkey, 645 S.W.2d 770, 772 (Tex. 
Kansas, however, has adopted a different view. ${ }^{190}$ In Cosgrove $v$. Young, the court viewed the vesting event for non-participating royalty interests as the time in the future when oil and gas royalties become payable under an oil and gas lease. ${ }^{191}$ Because it is possible that leases might not ever be executed, "there would never be a vesting of title to any royalty interest." 192 Cosgrove was decided in 1982 and relied on a 1951 decision, Lathrop v. Eyestone. ${ }^{193}$ In addressing calls to overrule Lathrop, the Cosgrove court responded, "[w]e are not unmindful that some other jurisdictions might well reach a different result" regarding the rule against perpetuities' application to non-participating royalty interests. ${ }^{194}$ However, the court refused to retreat from Lathrop, concluding "we see no compelling reason for change." 195

Several writers, including a strong dissenting opinion in Cosgrove, have asserted compelling reasons for change, such as a treatise's prediction that the Kansas view would lead to an inefficient "division of minerals into small shares held in common."196 That prediction recognizes that courts faced with the mineral or royalty issue stretch for a mineral determination in order to avoid the rule against perpetuities' application. ${ }^{197}$ One example is Shepard v. John Hancock Mutual Life Insurance Co., noted above for embracing the estate misconception in

1982) (finding that a top deed worded to postpone vesting until termination of bottom lease violated rule against perpetuities).

190. Unlike other states, Kansas views an non-participating royalty interest as personal property rather than real property. See Shepard v. John Hancock Mut. Life Ins. Co., 368 P.2d 19, 23-24 (Kan. 1962) (stating that as a right to share in production, royalties are personal property while mineral interests refer to an interest in resources "in and under the land" and are therefore interests in real property). However, the Kansas decisions regarding whether non-participating royalty interests violate rule against perpetuities do not focus on that distinction.

191. 642 P.2d 75, 84 (Kan. 1982).

192. Id.

193. Id. at 78-83 (citing Lathrop v. Eyestone, 227 P.2d 136 (Kan. 1951)).

194. Cosgrove v. Young, 642 P.2d. 75, 84 (Kan. 1982).

195. Id.

196. Id. at 89 (Herd, J., dissenting) (pointing out the inconsistencies between the Lathrop rule and the treatment of other interests comparable to royalties) (quoting 2 WILLIAMS \& MEYERS, supra note 103, at \$ 324.4); see also Burney, A Pragmatic Approach, supra note 14, at 47 (emphasizing the dissent's policy arguments).

197. See Brief of Amicus Curiae at 8-11, Rucker v. Delay, 289 P.3d 1166 (Kan. 2012) (No. 101,766), 2011 WL 3575902, at *8-11 (noting that if the interest is a mineral interest it avoids the question of the rule against perpetuities altogether); see also David E. Pierce, Recent Developments in Nonregulatory Oil and Gas Law: Beyond Theories and Rules to the Motivating Jurisprudence, 58 INST. ON OIL \& GAS L. \& TAX'N 1, 3 (2007) (arguing that stretching interpretations to find mineral interests to avoid the rule against perpetuities is a bad precedent to set). 
resolving the conflicting fractions issue. ${ }^{198}$ That case also considered whether the deed created a non-participating royalty rather than a mineral interest. ${ }^{199}$ The district court had agreed with the royalty determination for some of the interests, and invalidated them under the rule against perpetuities. $^{200}$

The Kansas Supreme Court, however, found it "unnecessary that we pass upon that question," because it viewed the disputed interest as a mineral interest. ${ }^{201}$ In reaching its conclusion, the court invoked the estate misconception, a "redundancy analysis" reminiscent of the French opinion, and discounted the royalty label in deference to a recital in a mortgage and "some sixty other words." 202 With a nod to the rule against perpetuities' destructive effect, the court held that the "defendant reserved an estate in real property which was vested in it upon delivery of the deed. To hold otherwise would result in the destruction rather than the construction of the property interest intended to be reserved."203

In Drach v. Ely, a case decided twenty years after Shepard, the Kansas Supreme Court again avoided the rule against perpetuities by interpreting a grant as creating a non-participating mineral interest. ${ }^{204}$ In reviewing the court's analysis, one commentator criticized the court for not having adopted a "more forthright" approach:

Ironically, the grantor's express retention of these elements of a mineral interest helped to establish, in the court's view, that the conveyed interests were mineral interests and not royalty interests. The court concluded that the conveyance was of undivided shares of the mineral estate, nonparticipating in rentals and bonuses. Consequently, the conveyance did not violate the rule against perpetuities, as it would have if the court had construed it to be the conveyance of royalty interests. This result was prompted, in part, by the general view that courts should favor a construction that complies with the rule against perpetuities over one that violates the rule. A more forthright approach would have been to overrule the Kansas view that perpetual

198. 368 P.2d 19, 22-27 (Kan. 1962) (overturning the district court's decision that the deed conveyed a royalty that violated the rule against perpetuities and instead held that a mineral interest was reserved).

199. Id. at 24-27.

200. Id. at 22 .

201. Id. at $22,26$.

202. Id. at 23-27. "Hence, had the parties intended the defendant to reserve only a royalty interest there would have been no necessity to make the reservation nonparticipating as to bonuses and delayed rentals since the plaintiffs would have been entitled to them as owners of the surface and of all the minerals in place in fee." $I d$. at 25 .

203. Id. at 26.

204. Drach v. Ely, 703 P.2d 746, 751 (Kan. 1985). 
nonparticipating royalty interests violate the rule against perpetuities. Kansas is alone in holding this view, which is unsupported by logic or policy.

a. Rucker v. DeLay: A Partial Retreat from the Rule Against Perpetuities Precedent

The current oil and gas production boom provided the Kansas Supreme Court with another opportunity to overrule the Kansas view. Rucker v. DeLay, decided in 2012, involved a dispute over a reservation in a 1924 deed from landowners who sold their surface and minerals estate in Barber County, ${ }^{206}$ where "the future of the Kansas gas and oil industry is happening now." ${ }^{207}$ The trial court had held that the reserved interest created a non-participating royalty interest. ${ }^{208}$ The appellate court agreed and "reluctantly" ruled the reserved interest was therefore void under Kansas rule against perpetuities precedent. ${ }^{209}$

In reaching its decision in Rucker, the Kansas Supreme Court acknowledged calls to overrule Cosgrove and Lathrop. ${ }^{210}$ For example, Professor David Pierce filed a persuasive amicus curiae brief, in which he acknowledged that in order to preserve the stability of land titles, courts should not rush to overrule rules of property. ${ }^{211}$ However, because the Kansas view encouraged creative interpretations to avoid the unintended destruction of interests, he urged the court to correct the Cosgrove and Lathrop views on the rule against perpetuities' application

205. Phillip E. DeLaTorre, Recent Developments in Kansas Oil and Gas Law (1983-1988), 37 U. KAN. L. REV. 907, 925-26 (1989) (citations omitted). I have urged courts to adopt a more forthright or pragmatic approach to the application of the rule against perpetuities to oil patch interests. See Burney, A Pragmatic Approach, supra note 14, at 45 (criticizing courts for creatively avoiding the rule against perpetuities' effects rather than openly exempting them from the rule).

206. 289 P.3d 1166, 1168 (Kan. 2012).

207. See Gale Rose, Gov. Brownback Sees Current Oil and Gas Techniques During Barber County Visit, PRATT TRIBUNE (Sept. 28, 2011, 11:37 AM), http://www.pratttribune.com/article/20110928/NEWS/309289932 (proclaiming that, "[t]he future of the Kansas gas and oil industry is happening now in Barber County").

208. Rucker v. DeLay, 289 P.3d 1166, 1168 (Kan. 2012).

209. Id. at 1169 . The reserved language provided: "The grantor herein reserves $60 \%$ of the land owner's one-eighth interest to the oil, gas or other minerals that may hereafter be developed under any oil and gas lease made by the grantee or by his subsequent grantees." Id. at 1168 .

210. Id. at 1172.

211. Brief of Amicus Curiae supra note 197, at $* 7$. 
to non-participating royalty interests. ${ }^{212}$

In the end, Rucker only partially heeded calls to "right the ship" regarding the rule against perpetuities and non-participating royalty interests. While the court recognized the errors of viewing production as the "vesting" event for non-participating royalty interests, it declined to "overrule our caselaw holding royalty interests created in a transferee are future interests that vest at production because that issue is not squarely before us." 13 Instead, the court held that the reserved royalty interest in the 1924 deed was vested, and therefore not subject to the rule against perpetuities. $^{214}$

In addition to an over-zealous exercise of judicial restraint, the court's decision turned on a flawed analysis of the common law rule. The court begins by noting that as it developed at common law, the rule against perpetuities applies to certain future interests. ${ }^{215}$ By definition, a "future interest" is a presently owned non-possessory interest, which may become possessory in the future. ${ }^{216}$ According to the common law development of the rule, however, the rule against perpetuities applies only to certain future interests, contingent remainders and executory interests. ${ }^{217}$ The rule does not apply to other vested future interests. ${ }^{218} \mathrm{~A}$

212. Id. at *8 (urging the court to take "necessary action to remedy the situation so Kansas district courts are not forced to address the issue on a case-by-case basis through reformation" under state statute).

213. Rucker, 289 P.3d at 1173.

214. See id. at 1172-73 (noting the criticism of the Kansas approach in that the rule against perpetuities does not apply to vested interests and subsequently not applying the rule against perpetuities to this reservation). The court also noted that Kansas had adopted the Uniform Rule Against Perpetuities, which supersedes the common law rule; however, it applies only to interests created after 1992. Id. at 1170. Professor Pierce, however, argued in his brief, that the statute had broader application. Brief of Amicus Curiae, supra note 197, at *8.

215. See Rucker, 289 P.3d at 1170 ("The common-law rule against perpetuities 'precludes the creation of any future interest in property which does not necessarily vest within twenty-one [21] years after a life or lives presently in being ....”') (quoting Singer Co. v. Makad, Inc., 518 P.2d 493, 496 (Kan. 1974)).

216. See Cornelius J. MoYNiHAN \& SHELdON F. KURTZ, InTROdUCtion to the LAW OF REAL PROPERTY 125 (3d ed. 2002) ("[Future] interests have a present existence even though enjoyment of possession is postponed.").

217. Id. at 244. For a discussion of the application of the rule against perpetuities to other oilpatch interests, top leases and deeds, and reserved term interests, see generally Burney, A Pragmatic Approach, supra note 14, at 40-54 (outlining the history of the rule against perpetuities in the oil patch).

218. The rule against perpetuities applies to contingent remainders and executory interests, but the rule will not void those interests if they vest, if at all, within 21 years from lives in being at the creation of the interest, which is Gray's classic recitation of the rule against perpetuities. See 
classic example is the reversion retained by a grantor, who, owning an estate in fee simple, conveys only a life estate. Because he conveyed less than the fee simple estate he owned, the grantor has retained a reversion, a vested interest, exempt from the rule against perpetuities' application. ${ }^{219}$ The future interest label applies, not because the interest is not a presently-owned and vested interest, but because it will not become possessory until the future. Other future interests exempt from the rule against perpetuities' application include the possibility of reverter retained by the grantor of a fee simple determinable estate. ${ }^{220}$ In many jurisdictions, the oil and gas lease creates a fee simple determinable in the lessee, leaving the possibility of reverter in the lessor. $^{221}$ The lessor's interest is a vested future interest, an interest that becomes possessory only upon termination of the lease. ${ }^{222}$

In sum, vested future interests, whether created by grant or reservation, are exempt from the rule against perpetuities' application, a fact the Rucker opinion notes. ${ }^{223}$ Yet in the end the court retreated from the general vested category, and restricted its ruling to the exemption accorded to reversions, the interests retained by grantors. ${ }^{224}$ Because the interest at issue was reserved by the grantor, the court overruled Cosgrove and Lathrop only as to reserved interests. ${ }^{225}$ The court's narrow holding guarantees more shale era disputes in Kansas over interests that may or may not be interpreted as non-participating royalty

MOYNIHAN \& KURTZ, supra note 216, at 243 (espousing Gray's classic recitation of the rule against perpetuities).

219. When the life estate ends, the grantor assumes the right to possession, and his fee simple interest is complete. See id. at 126-28 (summarizing the common law concept of reversions).

220. 1 ERnest E. SMith \& JaCQueline L. Weaver, TeXas LaW of Oil \& Gas § 3.9(E), at 378 ( 2 d ed. 2013) [hereinafter 1 ERnEST E. SMITH \& JACQueLINE L. WEAVER] (noting that the possibility of reverter does not violate the rule against perpetuities).

221. The classic phrase creating a fee simple determinable is "so long as." See MoYNIHAN \& KURTZ, supra note 216, at 44 ("Typically, the fee simple determinable arises through the use of the ... phrase[] 'so long as ...."'). Because that phrase appears in common oil and gas lease forms, early courts classified the lessee's interest as a fee simple determinable, which is also a vested interest exempt from the rule. See generally Burney, A Pragmatic Approach, supra note 14, at 4054 (citing early cases and decisions regarding the rule against perpetuities).

222. See 1 ERNEST E. SMITH \& JACQUELINE L. WEAVER, supra note 220, at 3-78 (“[A]

lessor ... retains a vested possibility of reverter ....").

223. See Rucker, 289 P.3d at 1171 (reciting Gray's classic recitation of the rule).

224. See id. at 1173 (declining "to extend the [court's prior vesting analysis] to royalty interests reserved in the grantor").

225. See id. ("[W]e need not determine in this case whether we should overrule our caselaw holding royalty interests created in a transferee are future interests that vest at production ...."). 
interests. When presented with another chance to "right the ship,"226 which the court purported to do in Rucker, the Kansas Supreme Court should complete the process and view non-participating royalty interests as vested interests, whether created by grant or reservation, which are exempt from the rule against perpetuities' application. That view reflects common law precedent and the view of writers who uniformly argue that the rule against perpetuities has no business in the oil patch. ${ }^{227}$

\section{THE MEANING OF “MineRALS": DOES IT INCLUDE OIL AND GAS?}

\section{A. The Pennsylvania Problem: The Dunham Rule}

While Kansas courts grappled with applying the decades-old rule against perpetuities precedent to non-participating royalty interests in the shale era, Pennsylvania courts recently faced an 1882 case when examining the meaning of "minerals." In most jurisdictions, the term "minerals" includes oil and gas. ${ }^{228}$ Pennsylvania, however, formulated a different rule in Dunham v. Kirkpatrick. ${ }^{229}$ The Dunham rule has been recognized to allow a rebuttable presumption "if, in connection with a conveyance of land, there is a reservation or an exception of 'minerals' without any specific mention of natural gas or oil,... the word 'minerals' was not intended by the parties to include natural gas or oil." 230 Addressing the Dunham rule in a 1960 case, Highland $v$. Commonwealth, the Pennsylvania Supreme Court refused to depart from

226. Id

227. See, e.g., Brief of Amicus Curiae, supra note 197, at 7 (arguing that applying the rule against perpetuities to the defendants' oil and gas lease would be an unnecessary expansion of the rule). See generally Burney, A Pragmatic Approach, supra note 14, at 40-54 (describing the applicability of the rule against perpetuities to oil and gas leases in different jurisdictions). Note that a Uniform Rule should help. See id. (describing the problems with piecemeal exceptions to the rule against perpetuities that could be remedied by adopting a uniform exception to the rule against perpetuities for oil and gas leases).

228. See McCormick v. Union Pac. Res. Co., 14 P.3d 346, 349-51 (Colo. 2000) (adopting the majority position and reviewing views taken by other courts, noting that "only a few jurisdictions in the eastern United States take the position that oil and gas are not included within the term "minerals"); HEMINGWAY, supra note 155, at 8 ("[A] majority of states have concluded that the term 'minerals' includes oil and gas ....').

229. See Dunham v. Kirkpatrick, $101 \mathrm{~Pa}$. 36, 40 (1882) (“'[T]he words 'all minerals,' used in the exception and reservation in the article of agreement and the deed mentioned in the case stated, do not, in common and ordinary meaning, include petroleum.").

230. Butler v. Charles Powers Estate, 65 A.3d 885, 888 (Pa. 2013) (quoting Highland v. Commonwealth, 161 A.2d 390, 398-99 (Pa. 1960)). 
this "rule of property":

The [Dunham Rule] has been the law of [Pennsylvania] for [many years] and very many titles to land rest upon it. It has become a rule of property and it will not be disturbed.... [T] hat the word 'minerals' appears in a grant, rather than an exception or a reservation, in nowise alters the rule.

Predictably, property owners questioned the Dunham rule in a dispute over Marcellus shale gas. Butler v. Charles Powers Estate involved the interpretation of a reservation in an 1881 deed of "minerals and Petroleum Oils." 232 The trial court had applied the Dunham rule and held this phrase did not include Marcellus gas. ${ }^{233}$ In remanding this ruling, the superior court sanctioned introduction of scientific and historic evidence about the Marcellus shale and the natural gas contained therein. ${ }^{234}$ The Pennsylvania Supreme Court granted review to determine "whether the Superior Court erred in remanding the case" to trial. ${ }^{235}$ As described below, on April 24, 2013, the Pennsylvania Supreme Court decided the superior court had erred and reinstated the trial court's ruling.

231. Highland, 161 A.2d at 398-99 (quoting Preston v. S. Penn Oil Co., 86 A. 203, 204 (Pa. 1913)). A vigorous dissent in Highland noted that:

In order to arrive at the conclusion reached by the Majority, one must find that practically everyone involved in writing conveyances, drafting Court orders, preparing documents and presenting exhibits desired to mock the English language, make sport of rules of grammar, distort the meaning of the simplest words, and ignore the sequence of cause and effect....

We must do all these things, which deride the purpose of language, are cynical of the dictionary, do violence to logic, upset Court decisions, and, worst of all, establish a precedent which will puzzle the learned, confuse the unlearned, and introduce into the law of real estate a quality of instability as fugacious as the natural gas which is the subject of this lawsuit.

Id. at 409 (Musmanno, J., dissenting). The Pennsylvania Supreme Court also addressed the Dunham rule in a 1906 opinion, Silver v. Bush. 62 A. 832 (Pa. 1906) (affirming Dunham in that the reservation of "minerals" did not include petroleum and, therefore, also did not include natural gas).

232. Butler v. Charles Powers Estate, 29 A.3d 35 (Pa. Super. Ct. 2011).

233. See id. at 42-43 (noting that the trial court held that, according to Dunham, "a reservation in a deed of 'all minerals' did not include petroleum oil").

234. Id. at 43.

235. Order Granting Petition for Allowance of Appeal, 41 A.3d 854 (Pa. 2012) (per curiam). 


\section{The "Public Reliance" Factor}

The Butler case had garnered attention among lawyers and laypeople, many reiterating the concern voiced in the Highland opinion:

If the Supreme Court were to revisit the Dunham Rule and modify it in any meaningful way, it would have the potential to cause significant chaos in the oil and gas industry in Pennsylvania.... People in Pennsylvania have understood that this is the way you wrote deeds since the $1880 \mathrm{~s}$.

\section{Did Dunham Create a "Rule of Property" or a "Rule of Construction?"-Does it Matter?}

The views expressed above suggest that Pennsylvania courts and residents have viewed the Dunham rule as a rule of property. As Professor Pierce noted in his amicus curiae brief in Rucker, courts should exercise restraint before overruling a rule of property. ${ }^{237}$ The justification for preserving such rules - as reflected in the concern about creating "chaos" in the quote above - is the need for certainty in drafting and interpreting titles. ${ }^{238}$ In light of the deference accorded to rules of

236. Sophia Pearson \& Mike Lee, Pennsylvania High Court Takes Appeal on Marcellus Shale Rights, BLOOMBERG BuSINESSwEEK (Apr. 5, 2012), http://www.businessweek.com/news/2012-0405/pennsylvania-high-court-takes-appeal-on-Marcellus-Shale-rights; see also Dale A. Tice, Opening Pandora's Box? Calling Shale Gas Rights into Question, 34 PA. LAW. 24 (Mar./Apr. 2012) ("Uncertainty is exactly what oil and gas lawyers in Pennsylvania are living with now following the Superior Court decision in Butler v. Charles Powers Estate, 29 A.3d 35 (Pa. Super., Sept. 7, 2011).").

237. See Brief of Amicus Curiae, supra note 197, at *7 ("Rules of Property, Even 'Bad' Ones, Should Rarely Be Changed."). Regarding the rule against perpetuities' application to nonparticipating royalty interests, Professor Pierce argued that the Kansas courts had incorrectly applied the "rule of property." Id. at *4-5.

238. See, e.g., Moser v. U.S. Steel Corp., 676 S.W.2d 99, at 103 (Tex. 1984) (declining to overrule retroactively the "surface destruction" test for interpreting the phrase "other minerals" in light of public reliance on prior law); see also United States v. Title Ins. \& Trust Co., 265 U.S. 472, 486-87 (1924) (“"Where questions arise which affect titles to land, it is of great importance to the public that, when they are once decided, they should no longer be considered open. Such decisions become rules of property, and many titles may be injuriously affected by their change." (quoting Minn. Mining Co. v. Nat'l Mining Co., 70 U.S. 332, 334 (1865))). See generally Laura H. Burney, "Oil, Gas, and Other Minerals" Clauses in Texas: Who's On First?, 41 Sw. L.J. 695, 714 (1987) (discussing protection accorded to rules of property to protect property rights) [hereinafter Burney, Who's On First]. For a general discussion of the difference between a "rule of property" and a "rule of construction" see RESTATEMENT (FIRST) OF PROP.: FUTURE INTERESTS pt. III intro. note (1940) (noting that rules of property and rules of construction are distinct, but nevertheless "have certain points of contact and similarity"). 
property, courts in general should consider whether rules affecting mineral titles fall in that category.

Historically, courts have differentiated between rules of property and rules of construction. "Rules of property" apply to set terms or words as a matter of law, regardless of the intent of the parties; a "rule of construction", on the other hand, applies only as an interpretative aid for ascertaining the intent of the parties. ${ }^{239}$ Rules of property contribute to title stability because title examiners can confidently determine property rights from the four-corners of documents. Rules of construction, by contrast, permit fact-finding determinations before meaning can be applied to the same terms appearing in different documents. ${ }^{240}$ However, such case-by-case determinations create uncertainty for drafters and title examiners.

The rule against perpetuities discussed in the previous section provides a classic common law example of a rule of property. The rule against perpetuities applies to certain interests, possibly leading to their invalidation, even if its application frustrates the intent of the parties. ${ }^{241}$ Indeed, this intent frustrating feature fuels calls to reject certain rules of property. ${ }^{242}$ When courts or legislatures take this step, however, they

239. See MOYNIHAN \& KURTZ, supra note 216, at 183 (noting that the Rule in Shelley's Case was held "in accordance with the English view, [to be] a positive rule of law, not a rule of construction, that is, that its operation did not depend on the intention of the conveyor or testator but would apply, if its requirements were satisfied, regardless of the transferor's intention").

240. See generally ReSTATEMENT (THIRD) OF PROP.: WiLls \& OTHER DONATIVE TRANSFERS $\S 11.2$ (2003) (outlining when extrinsic evidence can be used along with rules of construction to determine intent). Another common law rule, the Doctrine of Worthier Title, was effectively converted from a rule of property to a rule of construction in a famous opinion written by Justice Cardozo in Doctor v. Hughes. 122 N.E. 221, 222 (N.Y. 1919) (noting that originally, the Doctrine of Worthier Title "was a rule, not of construction, but of property"). "The importance of the court and the eminence of the judge who wrote the opinion gave the rule a prominence it had previously lacked and changing the rule from a positive rule of law to one of construction appeared to have the merit of effectuating the intention of the grantor." MOYNIHAN \& KURTZ, supra note 216, at 197.

241. As noted in the previous section, in light of the rule against perpetuities' blanket application to certain non-vested interests, courts have avoided its application to non-participating royalty interests by viewing them as vested interests. See supra notes 200-01 and accompanying text.

242. A classic example from common law is the "Rule in Shelley's Case." That rule provides that if a grant is made to a life tenant followed by a remainder in that life tenant's heirs, the remainder is rewritten to create a vested remainder in the life tenant. The point of the rule was to allow merger to occur, leaving the life tenant with a fee simple absolute. Common law courts designed the rule to apply regardless of the parties' intent to promote feudal policies that preferred fee simple estates. When that rule crossed the Atlantic, states struggled with whether to overrule this "rule of property," expressing concern that parties had relied on its ultimate effect. Many courts 
generally overrule them prospectively rather than retroactively. The justification for a "prospective only" approach is the public's reliance on rules and their effects on drafting and interpreting documents. ${ }^{243}$

Although the Dunham rule has been viewed as a rule of property, the courts' descriptions reflect a rule of construction by permitting consideration of parties' intent. The Dunham opinion states that the word "minerals" creates not a set meaning as a matter of law but "a rebuttable presumption that the grantor did not intend for 'minerals' to include natural gas or oil.",244 Highland's reiteration of the rule in 1960 expressly refers to it as both a rule of property and a rule of construction: "In [Dunham] this Court enunciated a rule of construction of the word 'minerals' to be applied when determining the inclusion therein or the exclusion therefrom of natural gas or oil. This decision established a rule of property ...." ${ }^{245}$ Yet Highland continues to describe not a set rule but a presumption rebuttable by "clear and convincing evidence that the parties to the conveyance intended to include natural gas or oil within such word." 246

In Butler, the trial court adopted the rule of property view of Dunham. $^{247}$ In appealing that ruling, the owners of the reserved "minerals" interest argued the trial court erred under that categorization

reluctantly applied Shelley's Rule when raised by the words in conveyances, and awaited legislative action to overrule it. See Moynihan \& KURTZ, supra note 216, at 181-91 (outlining the development and operation of the rule).

243. See, e.g., TeX. Prop. Code AnN. $\$ 5.042$ (West 2012) (abolishing the Rule in Shelley's Case and stating that conveyances that took effect twenty years before the statute's enactment will not be affected); Moser, 676 S.W.2d at 103 (overruling the "surface destruction test" prospectively only in light of public's reliance); see also Burney, Who's On First, supra note 238, at 712-15 (citing Great N.Y. v. Sunburst Oil \& Ref. Co., 287 U.S. 358, 365 (1932)) (opining that courts should consider whether ruling affects title stability when deciding whether to overrule prospectively or retroactively). In that article I argued that the Texas Supreme Court should have retroactively overruled the "surface destruction test" for determining whether the phrase "other minerals" included uranium because that test required factual inquiries; therefore, parties could not have relied on it as a matter of law. Id. at 696. The Dunham definition, however, arguably established a set, even if misguided, definition of the word "minerals."

244. Butler v. Charles Powers Estate, 29 A.3d 35, 40 (Pa. Super. Ct. 2011), rev'd sub nom Butler v. Charles Powers Estate, 65 A.3d 885 (Pa. 2013) (citing Dunham v. Kirkpatrick, 101 Pa. 36, 42 (1882) (doubting that the term mineral includes petroleum and stating that where a term's meaning is doubtful, it must be construed against the grantor).

245. Highland v. Commonwealth, 161 A.2d 390, 398 (Pa. 1960).

246. Id. at 399.

247. See Butler, 29 A.3d at 37 (noting that the trial court dismissed the plaintiff's "request for a declaratory judgment that natural gas is included in the reservation of the deed"). 
of the rule. ${ }^{248}$ First, they argued the Dunham rule, excluding gas from the word "minerals," should not apply to the Butler deed since it predates the Dunham opinion by a year. ${ }^{249}$ In light of that chronology, the argument that drafters relied on Dunham's definition as a rule of property could lose force. ${ }^{250}$ Second, the "minerals" owners distinguished Dunham, arguing it involved conventional rather than shale gas, "and no Pennsylvania decision has decided that mineral rights exclude Marcellus shale." ${ }^{251}$ In remanding, the superior court focused on that second point:

The Dunham and Highland decisions do not end the analysis, absent a more sufficient understanding of whether, inter alia (1) Marcellus shale constitutes a 'mineral'; (2) Marcellus shale gas constitutes the type of conventional natural gas contemplated in Dunham and Highland; and (3) Marcellus shale is similar to coal to the extent that whoever owns the shale, owns the shale gas.

\section{Butler v. Charles Powers Estate: Reaffirming Dunham for the Shale} Era

The Pennsylvania Supreme Court agreed to review the superior court's Butler ruling on April 3, 2012. ${ }^{253}$ A year later, the supreme court reinstated the trial court's ruling, determining that "the Dunham Rule has now been an unaltered, unwavering rule of property law for 131 years; indeed its origins actually date back to the [1836] Gibson decision,

248. See id. at 38 (noting that the only issue raised on appeal was "whether ... [the trial court] erred in determining that the ... reservation in the chain of title to the surface land currently owned by ... appellees did not include a reservation of one half of such unconventional Marcellus shale gas as might be found under the land").

249. Reply Brief of Appellants, at *3-4, Butler v. Charles Powers Estate, 29 A.3d 35 (Pa. Super. Ct. 2011) (No. 1795 MDA 2010), 2011 WL 3342735. In fact, the owners of the reserved "minerals" argue that prior to Dunham the word included natural gas. Id. They also note that the Highland deeds were executed after the Dunham decision; therefore, neither case is controlling. Id. at *5.

250. See id. at *3 ("The significance of this sequence is that, as of the date of the deed and the subject reservation, the Dunham decision was totally unknown to the scrivener who wrote the subject reservation. Had the scrivener been a close and diligent student of the Supreme Court of Pennsylvania, he or she could never have imagined that the Pennsylvania Supreme Court would create such a glaring departure from so many years of contract and deed construction.").

251. Butler, 29 A.3d at 39 .

252. Id. at 43. The "minerals" owners relied on U.S. Steel Corp. v. Hoge, 468 A.2d 1380 (Pa. 1983), which held that coalbed methane gas belongs to the owner of the coal. Id. Similarly, the "minerals" owners in Butler claimed that the owners of the shale owned the shale gas. Id.

253. Order Granting Petition for Allowance of Appeal, supra note 235. 
placing the rule's age at 177 years." ${ }^{254}$ Having clarified that the Dunham rule predated the 1882 Dunham decision, the court rejected the claim that the rule should not apply to the 1881 deed in Butler. ${ }^{255}$ Additionally, while the court repeatedly applied the rule of property moniker, it continued to recognize that the Dunham rule permits consideration of parol evidence of the parties' intent when executing the deed. ${ }^{256}$

As explained above, the Pennsylvania Supreme Court's definition of Dunham reflects a rule of construction, which opens the door to case-bycase decisions that detract from title stability. ${ }^{257}$ A concurring justice recognized this distinction. Although that justice viewed Dunham as "cryptic, conclusory, and highly debatable," 258 Justice Saylor focused on the extent of public reliance and would have clarified its "rule of property" status: "In this regard, on account of Dunham's shortcomings, I find the 'rule of property law' denominator more accurate than a characterization of Dunham as a sustainable effort to assess the actual intentions of the parties to a conveyance." 259

The concurring justice also appeared to note another option, discussed above, ${ }^{260}$ for replacing cryptic rules with those that promote title stability: ruling prospectively only from the date of the opinion. ${ }^{261}$

254. Butler, 65 A.3d at 897. The Gibson case to which the court refers was decided in 1836.

255. See id. at 898 ("[I]n 1881, the law of Pennsylvania was Gibson ....").

256. See id. ("[T] $]$ he rule in Pennsylvania is that natural gas and oil simply are not minerals .... [The intention to include natural gas within the deed reservation] may only be shown through parol evidence....").

257. See supra Part II.C.1.

258. Id. at 899 (Saylor, J., concurring).

259. Id. at $900 \mathrm{n} .1$.

260. See supra notes $243-46$ and accompanying text (arguing that the historical understanding of "rules of property" should be given great deference because many people relied on that understanding of the rules).

261. See id. at 900 (noting that in light of the public reliance on Dunham, the court could not overrule it retroactively). Rules and statutes that affect titles are often restricted by dates. See, e.g., Mont. CodE ANN. § 82-1-111 (1993) (defining “coal," "gas," and "oil," prospectively from 1993); Moser, 676 S.W.2d at 103 (limiting ruling prospectively to deeds executed after date of opinion). Arkansas followed a trek similar to Pennsylvania's with the Strohacker doctrine, which limited the meaning of conveyances of "valuable mineral deposits" to minerals "known to be valuable at the time of the grant." Mo. Pac. R.R. Co. v. Strohacker, 152 S.W.2d 557, 563 (Ark. 1941) (holding that the reservation of "all coal and mineral deposits" in 1892 was ineffective to reserve oil and gas). A recent Arkansas Supreme Court case, however, narrowed that doctrine and adopted a date-specific approach for the meaning of "minerals." See Staggs v. Union Pac. R.R. Co., No. 11-902, 2012 WL 1222225, at *5 (Ark. Apr. 12, 2012) (noting that "between 1905 and 1937, it became common knowledge in Arkansas that a reservation of mineral rights included oil and gas"); see also Jamie G. Moss, Comment, The Strohacker Doctrine: Its Application in Arkansas Courts and the Need for an 
Indeed, the Butler dispute presented the Pennsylvania Supreme Court with the opportunity to change the law prospectively and adopt an expansive definition of the term "minerals," one that includes oil, and gas, including Marcellus gas. ${ }^{262} \mathrm{~A}$ broad definition of minerals, as scholars and courts have explained, decreases litigation and increases title stability, which should be the guiding goal in the shale era. ${ }^{263}$ However, the concurring justice viewed that approach as unnecessary for

Updated Rule, 64 ARK. L. REV. 1095, 1118-19 (2011) (urging courts to adopt a date-specific "bright line" rule to ensure title stability and encourage leasing in the current shale boom).

262. Writers support an expansive definition of the term "minerals" or "other minerals." See, e.g., Eugene O. Kuntz, The Law Relating to Oil and Gas in Wyoming, 3 WYO. L.J. 107, 112-13 (1948), reprinted in 34 OKLA. L. REV. 28, 34-35 (1981) ("Since the enjoyment of oil and gas is through extraction, it should be considered to be within a general grant or reservation of the minerals."). Interpreting "minerals" and "gas" as broadly as possible would also promote title stability. See Spurlock v. Santa Fe Pac. R.R. Co., 694 P.2d 299, 307 (Ariz. Ct. App. 1984) ("To alleviate these problems, many courts find the term minerals to be unambiguous. Under this approach title uncertainty is minimized and courts are able to avoid the tortuous process of attempting to discover the parties' specific intent."); see also KUNTZ, A TREATISE ON THE LAW OF OIL AND GAS, supra note 13, at 384 (promoting the idea that when there is a general severance the entire estate should be severed to promote stability); LowE, supra note 13, at 496 (preferring an expansive definition of "other minerals" because it avoids case-by-case searches for the parties' intent). Idaho recently had the chance to do just this and instead found the term "minerals" ambiguous instead of excluding geothermal resources from the definition. See Ida-Therm, LLC v. Bedrock Geothermal, LLC, 293 P.3d 630, 633-36 (Idaho 2012). On the contrary, a recent West Virginia opinion stressed the need to promote title stability in overruling a 1923 case that had required viewing the word "surface" as ambiguous, and instead adopted a broad definition of that term. Faith United Methodist Church \& Cemetery of Terra Alta v. Morgan, 745 S.E.2d 461, 464 (W. Va. 2013) (overruling Ramage v. S. Penn Oil Co., 118 S.E. 162 (W. Va. 1923)).

263. In a different context the Pennsylvania Supreme Court interpreted "minerals" more broadly. See Joseph Iole, May Two Laws Occupy the Same Space at the Same Time? Understanding Pennsylvania Preemption Law in the Marcellus Shale Context, 6 APPALACHIAN NAT. ReS. L.J. 39, 42 (2011-2012). Iole notes that:

Because the debates are so nuanced, some contests among the ever-changing cast of characters (each somehow involved in or affected by gas extraction from the Marcellus shale) have led to peculiar results. For example, one contest involves the interpretation of "mineral extraction." In Huntley \& Huntley v. Borough Council of Oakmont [sic], the Pennsylvania Supreme Court upheld the Commonwealth Court's finding that natural gas drilling falls within the category of "mineral extraction," leading to the determination that the Borough had to grant a special use permit for the drilling activity. Counterintuitively, when determining property rights from certain mineral leases, "minerals" could take on a nuanced definition that does not include natural gas. This assault on logical consistency, which is generally a by-product of the legal objective to determine the drafter's intent, could also illustrate that not all contests in the "oil and gas development" have the same stakes involved. Whether debating property rights or intrastate preemption, it is important to identify the interested parties.

Id. at $42-43$. 
this reason: the effects of the Dunham decision can easily be avoided with careful drafting. ${ }^{264}$ In fact, drafters can and have avoided Dunham's dictates by expressly mentioning oil and gas. For example, in a recent Marcellus shale case, Kowcheck v. Pittsburgh Terminal Realization Corp., the court held that Dunham was irrelevant to the interpretation of a 1946 deed that reserved "all oil and gas under said tracts of land together with the right and privilege of drilling and removing said oil and gas ....,",265

Rather than alter Dunham prospectively, the Pennsylvania Supreme Court in Butler retained and reaffirmed the Dunham rule. ${ }^{266}$ In the process, the court repeated rule of construction verbiage. However, its restrictive approach permits rule of property effects. Specifically, the court emphasized that overcoming the Dunham presumption requires "clear and convincing" evidence of the parties' intent, and not other evidence at the time the deed was executed-a difficult burden for parties to meet. ${ }^{267}$ Another recent Marcellus shale dispute from Pennsylvania illustrates not only the difficulty of this burden but courts' preference to avoid fact-based inquiries about intent. In Elbow Fish \& Game Club, Inc. v. Guillaume Business Opportunity Group, the court rejected pleas to await the Pennsylvania Supreme Court's ruling in Butler. ${ }^{268}$ Instead, the court concluded that summary judgment was

264. See Butler, 65 A.3d at 900 (Saylor, J., concurring) ("Finally, I note that, in terms of modern conveyances, the parties certainly have the ability to negate the impact of the Dunham decision by making their intentions clear on the face of the written instrumentation. This lessens the need for this Court to consider fashioning a new, prospective rule.").

265. See Kowcheck v. Pittsburgh Terminal Realization Corp., No. 2009-4328, 2011 WL 9753960 , at $* 3$ (Pa. Com. Pl. Civil Div. Nov. 14, 2011) (noting that, unlike the deed at issue in Dunham, the deed in the instant case does not require interpretation of the term "all minerals"). This opinion relies on a 1996 Pennsylvania Supreme Court case that had analyzed a deed that expressly referred to oil and gas. Id. (citing Sheaffer v. Caruso, 676 A.2d 204 (Pa. 1996)). In Kowcheck, the plaintiffs had argued that "gas" did not include Marcellus shale gas since that gas would have been unknown to the parties when the deed was executed. Id. The court rejected that view. See id. ("Here, the reservation language in the 1946 deed specifically reserves 'all oil and gas under said tracts of land'. Thus, there is no issue as to whether the gas rights were excepted and reserved by the deed.").

266. Butler, 65 A.3d at 899 (noting that the facts did not support deviating from the Dunham analysis and affirming the lower court's decision under Dunham).

267. Id. (holding that "under the Dunham Rule, the trial court correctly concluded on the averments of record that Marcellus shale natural gas was not contemplated by the private deed reservation presented in this case"). The court also rejected claims that its rulings regarding ownership of coalbed methane gas, or that the methods of producing Marcellus shale natural gas, required it to depart from Dunham. Id.

268. No. 12-00825, 2013 WL 1364007 (Pa. Com. Pl. Mar. 25, 2013). 
proper when the parties admitted that "all parties to the 1928 transaction have passed and that no direct evidence of the parties' intent exists."269 In its conclusion, the court reemphasized the significance of the Dunham rule, and described it with rule of property parameters: "Many titles to land within the Commonwealth rest upon the Dunham rule; this Court will abide by this long-standing rule of property until otherwise advised by our appellate courts." ${ }^{270}$ In light of the Butler decision, courts in Pennsylvania have been advised that the Dunham rule reigns in that state - whether viewed as a rule of property or rule of construction-for drafting and resolving title disputes involving the meaning of "minerals" in the shale era.

\section{$V$. The EXeCUTIVE Right AND CORRESPONDING DUTY: LESLEY V. VETERANS LAND BOARD}

As evidenced in the discussion of Butler, courts should consider public reliance on prior law in rulings that affect property rights. However, a recent Texas opinion, Lesley v. Veterans Land Board, ${ }^{271}$ fails to address that concern despite claims that it marked a turning point from prior law. ${ }^{272}$ That prior law consists of cases defining the duty owed by executives to non-executive owners. As with other perennial title issues discussed above, most executive-duty law emanates from Texas cases. ${ }^{273}$

269. Id. at *6.

270. Id. at $* 14-15$.

271. 352 S.W.3d 479 (Tex. 2011). The author served as appellate counsel for the developer in this case and argued on its behalf in the Texas Supreme Court.

272. See Christopher S. Kulander, The Executive Right to Lease Mineral Real Property in Texas Before and After Lesley v. Veterans Land Bd. of Tex., 44 ST. MARY's L.J. 529, 556 (2013) (noting Lesley departed from prior law); see also J. Robert Beatty and Monika Ehrman, The Nature of the Severed Executive Right, in STATE BAR OF TEXAS CLE 26 (2004) (noting before the Texas Supreme Court revisited In re Bass in Lesley that "[u]nder current Texas law, an executive does not breach a fiduciary duty to the non-executive if the executive does not exercise his right to execute an oil and gas lease").

273. In other states, extensive compulsory pooling statutes render the executive duty less significant. Texas's statute is not as comprehensive; therefore, in Texas, leases executed by executive right owners, plus the pooling clauses in those leases are key for field-wide development. See Laura H. Burney, The Texas Supreme Court and Oil and Gas Jurisprudence: What Hath Wagner \& Brown v. Sheppard Wrought?, 5 TEX. J. OF OIL, GAS, AND ENERGY L. 219, 225 (2010) [hereinafter Burney, The Texas Supreme Court and Oil]. The Texas Supreme Court and Oil provides:

Forming pooled units is essential in the oil and gas industry .... For that reason, most major producing states long ago passed compulsory pooling acts. Notoriously slow 
However, because these cases sent mixed messages, writers have recognized lingering uncertainty and have urged courts to provide clarification about the scope of the duty. ${ }^{274}$ Lesley, a shale era case, provided the Texas Supreme Court with that opportunity. ${ }^{275}$

\section{A. The Mixed Messages Regarding the Duty: Fiduciary or Utmost Good Faith?}

The Lesley opinion begins with the bundle of sticks analogy: "The right to lease minerals - the executive right — is one 'stick' in the bundle of five real property rights that comprise a mineral estate."276 Concerning the corresponding duty, the court initially notes that it "held long ago that the executive owes ... a duty of "utmost fair dealing,", but that it has "seldom had occasion to elaborate." 277 However, in prior cases, notably the notorious 1984 case Manges v. Guerra, ${ }^{278}$ the court

to follow that path, Texas passed an act in 1965 known as the Mineral Interest Pooling Act ('MIPA'). Unlike acts in other states, however, authorities view the MIPA as limited in function, less a compulsory act than an act to encourage voluntary pooling. In fact, in Texas pooled units formed pursuant to the MIPA are relatively rare.

Id. See generally 3 ERnest E. Smith \& Jacqueline L. Weaver, TeXas LaW of Oil and GaS $\S 12.5$ (2011) (noting the restricted nature of the Mineral Interest Pooling Act as compared to compulsory pooling acts in other states). Additionally, statutes governing development on state and federal lands generally preempt executive duty case law by mandating leasing practices and duties. See, e.g., Patrick H. Martin, Unbundling the Executive Right: A Guide to Interpretation of the Power to Lease and Develop Oil and Gas Interests, 37 NAT. RES. J. 311, 389 (1997) (describing that separate from case law, "Texas has a unique arrangement for certain of its public lands that are the subject of the Relinquishment Act”); see also State v. Durham, 860 S.W.2d 63, 66 (Tex. 1993) (holding that under the Relinquishment Act, which names the surface owner an agent for the state in leasing, the owner owes a fiduciary duty).

274. See Ernest E. Smith, Implications of a Fiduciary Standard of Conduct for the Holder of the Executive Right, 64 TEX. L. REV. 371, 406 (1985) (concluding that even after Manges, "[i]t may not, however, be too late to argue for a lesser standard than that of a fiduciary"); Norvell, supra note 104, at 981 (noting the "uncertainty that lingers as to the Manges decision's effect on the standard of care").

275. See Andarko Petroleum Corp. v. BNW Prop. Co., 393 S.W.3d 846, 850-52 (Tex. App.

2012) (noting that discovery of the Barnett shale prompted non-executives to sue executives in

Lesley).

276. 352 S.W.3d at $480-81$.

277. Id. at 481 (citing Schlittler v. Smith, 101 S.W.2d 543, 545 (Tex. 1937)).

278. 673 S.W.2d 180 (Tex. 1984). A year after the court decided the case, Professor Ernest Smith concluded that, "[a] case with the notoriety of Manges should not set the standard for landowners whose acquisition and use of the executive right involve none of the elements of overreaching apparently present in that case." Smith, supra note 274, at 406 . For a sample of the many articles discussing Manges, see, e.g., Douglas Martin, Clinton Manges, Volatile Texas Oilman 
had elaborated by combining the fiduciary label with the lower standard, "utmost good faith." 279 The court's use of that label has created confusion and elicited criticism. Applied in its traditional sense, that label suggests executives owe the high level of duty imposed in trust and agency relationships. ${ }^{280}$ That standard would require executives to subordinate their interests to the non-executives, a requirement commentators criticized as "onerous" and as a "deviation" from the utmost good faith standard previously adopted by Texas courts and courts of other jurisdictions. ${ }^{281}$

\section{B. In re Bass (Tex. 2003): No Duty to Lease, But No "Self-Dealing" When Leasing}

In a 2003 opinion, In re Bass, the court appeared to clarify that the duty established in Manges was not as "onerous" as the fiduciary label implied. ${ }^{282}$ Bass reached the court through a discovery dispute. ${ }^{283}$ Specifically, the non-executives, owners of a two percent nonparticipating royalty interest in a 22,000 acre ranch, sought to review seismic information obtained by Bass, the owner of the surface and

and Rancher, Dies at 87, N.Y. Times (Sept. 28, 2010), http://www.nytimes.com/2010/09/29/business/29manges.html?_r=0; Ken Case, Blind Justice: Is There Anything Wrong with a Justice of the Supreme Court of Texas Helping Out a Close Friend?, 15 TEX. MONTHLY 136 (1987).

279. Manges, 673 S.W.2d at $183-84$ (using the label "fiduciary duty" to refer to the duty of utmost good faith in the court's discussion of Manges' self-dealing). "Until the Texas Supreme Court's decision in Manges v. Guerra, the utmost good faith standard had not been considered to create a fiduciary duty." Mims v. Beall, 810 S.W.2d 876, 878 (Tex. App. 1991) (internal citation omitted). For a thorough discussion and criticism of the court's use of the fiduciary label in Manges, see Smith, supra note 274, at 406 (noting that Texas cases and most jurisdictions hold executives to the lower standard of care, utmost good faith, rather than a fiduciary standard).

280. See Smith, supra note 274, at 372-73 (noting that fiduciary duties are on the high end of the standard of behavior scale). For a recent opinion thoroughly reviewing Texas case law and the issues raised by a court's use of the fiduciary label, see generally Bradshaw v. Steadfast Fin. LLC, 395 S.W.3d 348 (Tex. App. 2013), reh'g granted.

281. Smith, supra note 274 , at 406 (describing the fiduciary standard for executives as "onerous" and as a "deviation" from prior law); see also Martin, supra note 273, at 396 ("Most writers have found that the nature of the oil and gas business does not warrant a fiduciary standard because the parties themselves do not suppose themselves to be establishing a fiduciary relationship.").

282. 113 S.W.3d 735, 745 (Tex. 2003).

283. Id. at 737 (noting that the issues in the case involve whether seismic data was protected from disclosure as trade secrets). 
minerals (the executive). ${ }^{284}$ The court first determined that the information was a trade secret and not discoverable, unless the nonparticipating royalty interest owners could prove that discovery was necessary for a fair adjudication of their claim. ${ }^{285}$ The court decided no necessity existed because the executive owed no duty to the nonexecutives until a lease was executed. ${ }^{286}$

In asserting their right to review the seismic information, the nonexecutives had relied on Manges. ${ }^{287}$ However, in Bass the court adopted a restrictive and fact-specific view of that 1984 case:

\begin{abstract}
Manges purchased one-half of the mineral estate and executive leasing rights from the Guerra family with the Guerras retaining the other $50 \%$ ownership interest in the mineral estate. The Guerras sued Manges for self-dealing in leasing a portion of the estate to himself at unfair terms. We stated that '[a] fiduciary duty arises from the relationship of the parties ... [t] hat duty requires the holder of the executive right, Manges in this case, to acquire for the non-executive every benefit that he exacts for himself. Accordingly, we held that Manges breached his fiduciary duty to the Guerras by making a lease to himself under numerous unfair terms.... Because Manges held that the executive owes the non-executive a fiduciary duty, the [non-executives] correctly state that Bass owes them a duty to acquire every benefit for [them] that Bass would acquire for himself. What differentiates this case from Manges, however, is that no evidence of self-dealing exists here. Bass has not leased his land to himself or anyone else.... Thus, the present facts are distinguishable from Manges.
\end{abstract}

Following In re Bass, commentators concluded that an executive owed no affirmative duty to lease, but when executing a lease, the executive must avoid self-dealing. ${ }^{289}$ Instances of self-dealing include leasing arrangements by executives designed to prevent non-executives

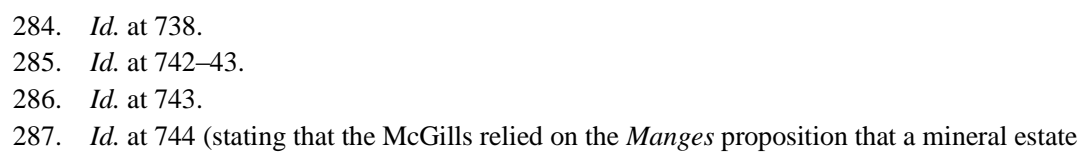

owner has a duty to develop the mineral estate).

288. Id. at 744-45 (citations omitted).

289. 1 ERNEST E. SMITH \& JACQUELINE L. WeAVER, TEXAS LAW OF OIL AND GAS § 2.6(C)(4), at 2-94 to -95 (2d ed. 2013) (noting that decisions subsequent to Manges had "refused to impose this level of diligence on the executive" and describing In re Bass as implying that the executive "is barred from obtaining a benefit for himself that is not shared with the nonexecutives" and that "there is no independent duty to lease, even though failure to do so may deprive the nonexecutives of any financial benefit from their interest"); Beatty and Ehrman, supra note 272, at 26 (noting that before the Texas Supreme Court revisited In re Bass in Lesley, "[u]nder current Texas law, an executive does not breach a fiduciary duty to the non-executive if the executive does not exercise his right to execute an oil and gas lease"). 
from sharing in higher bonuses and royalty rates. ${ }^{290}$ Courts also relied on In re Bass in concluding that executives did not owe an affirmative duty to lease and that the duty was not triggered until a lease had been executed. ${ }^{291}$ One of those cases was Lesley v. Veterans Land Board. ${ }^{292}$

C. Lesley v. Veterans Land Board (Tex. 2011)

1. Facts

In 1998 Bluegreen ("the developer"), bought for two million dollars about 4,100 acres of land in North Texas that the Lesleys and others (collectively, "the Lesleys") had conveyed to the developer's predecessor. ${ }^{293}$ The Lesleys' deed reserved a fraction of the minerals they already owned but conveyed all of the surface, remaining minerals, and "the 'full, complete and sole right to execute oil, gas and minerals leases" " to the developer. ${ }^{294}$ After the conveyances, the Lesleys became non-executives who owned fractional non-participating royalty interests. The developer owned the surface, the remaining fractional mineral interests in the property, and all of the executive rights. The developer developed the property into a residential subdivision, Mountain Lakes, imposed deed restrictions, and sold 1700 lots to various buyers, including the Veterans Land Board. ${ }^{295}$ In the deed to the buyers, the developer did not reserve the executive rights or minerals; therefore, the lot owners obtained a fractional share of minerals, including the corresponding

290. See, e.g., Luecke v. Wallace, 951 S.W.2d 267, 274-75 (Tex. App. 1997) (finding a breach of duty when executive leased to solely-owned company for $1 / 8$ royalty and $\$ 50$ an acre bonus and then assigned lease to original offeror for $1 / 5$ royalty and $\$ 150$ an acre bonus).

291. See, e.g., Aurora Petroleum, Inc. v. Newton, 287 S.W.3d 373, 376-77 (Tex. App. 2009) (" $[\mathrm{T}]$ here is no existing oil and gas lease. Therefore, there can be no implied duty to develop ...."); Hlavinka v. Hancock, 116 S.W.3d 412, 420 (Tex. App. 2003) ("[T]he executive did not breach a fiduciary duty to the non-executives without having exercised his executive power."). In Lesley, the Texas Supreme Court disapproves of both of these opinions. Lesley v. Veterans Land Bd. of Tex., 352 S.W.3d 479, 491 n.78 (Tex. 2011).

292. 352 S.W.3d 479 (Tex. 2011).

293. Veterans Land Bd. of Tex. v. Lesley, 281 S.W.3d 602, 609 (Tex. App. 2009).

294. Lesley, 352 S.W.3d at 481.

295. Id. at 481-82. The Veterans Land Board (VLB) asserted that sovereign immunity barred the non-executives' lawsuit against it; both the court of appeals and the Texas Supreme Court agreed with the VLB. Id. at 484 . 
executive rights in their lots. ${ }^{296}$

Seven years later, when the Barnett shale was booming, the Lesleys sued claiming the executives - the developer and the lot owners - had breached duties owed to them. ${ }^{297}$ The trial court granted summary judgment in favor of the Lesleys, which included rulings that the executives had breached their duties by (1) imposing deed restrictions that prohibited drilling, and (2) by failing to lease. ${ }^{298}$

\section{Court of Appeals}

The court of appeals disagreed with the trial court's rulings regarding the duty owed by the executives. ${ }^{299}$ Relying on In re Bass and its interpretation of Manges, the court held the executives' duties had not been triggered since they had not leased the minerals. ${ }^{300}$ Overall, the court found that the developer had acted properly by executing deeds of trust covering the surface and by imposing deed restrictions that prohibited drilling. ${ }^{301}$ In rejecting the Lesleys' analogies to Manges, the court stated that "the facts in this case are nothing like the facts in

296. The appellate court and the Texas Supreme Court opinions each relied on Day v. Texland Petroleum, 786 S.W.2d 667 (Tex. 1990), in deciding that the developer had not reserved executive rights when it sold each lot. Lesley, 352 S.W.3d at 486-87; Lesley, 281 S.W.3d at 616. The trial court, however, had ruled that the executive rights remained with the developer. Lesley, 281 S.W.3d at 612. The appellate and supreme court opinions also agreed that the right to develop was conveyed with the executive right, rejecting the non-executives' claim that they maintained the right to develop. Id. at 620; Lesley, 352 S.W.3d at 486-87. For an argument that the right to develop should be viewed as separate from the executive right see Kulander, supra note 272, at 576-77.

297. Lesley, 352 S.W.3d at 482 ("While Mountain Lakes was being developed, so was the Barnett Shale, a hydrocarbon-producing geological formation underlying this part of North Texas and possibly this subdivision."); see also Andarko Petroleum Corp. v. BNW Prop. Co., 393 S.W.3d 846, 850-51 (Tex. App. 2012) (noting that discovery of Barnett shale prompted the non-executives to sue executives in Lesley).

298. Lesley, 281 S.W.3d at 612.

299. Id. at 618-19. The court agreed that the developer had conveyed executive rights to the lot owners. Id. at 617 .

300. Id. at 619 .

301. Id. The non-executives had tried to equate the deeds of trust executed by the developer to those executed in Manges, but the court disagreed: "In Manges, the executive's deed of trust covered all mineral interests, including the executive right.... However, the deeds of trust that [the developer] executed did not purport to cover any mineral interests." Id. Moreover, the court held that executing deeds of trust and imposing deed restrictions, even if construed as an exercise of the executive right, did not breach the duty owed to the non-executives. Id. at 620 . 
Manges." $" 302$ Instead, the court focused on the parties' original bargain when the developer bought the property and all of the executive rights in 1998:

This case involves an arms-length transaction between the Lesley Appellees and [the developer]. [The developer] wanted to obtain property for the purpose of developing a residential subdivision .... The Lesley Appellees certainly knew that a residential developer would not want drilling or other similar activities to take place on the surface area in the subdivision. With that knowledge, the Lesley Appellees sold the property to [the developer] for about $\$ 2,000,000$. The Lesley Appellees could have negotiated to retain the executive rights.... Instead, the Lesley Appellees willingly conveyed the executive rights .... Based on the facts in this case ... [the executives] did not breach a fiduciary duty to [the non-executives].

Although the appellate court continued to use the fiduciary label, it adopted the restrictive view of that term reflected in In re Bass. In Lesley, the Texas Supreme Court, however, rejected not only the appellate court's rulings, but also its view of In re Bass and Manges.

\section{Texas Supreme Court Opinion}

Before addressing the legal questions, the court acknowledged shaleera economics:

While Mountain Lakes was being developed, so was the Barnett Shale.... Almost all the surrounding area came under lease for oil and gas production. There is evidence that Mountain Lakes is sitting on $\$ 610$ million worth of minerals that, in large part, cannot be reached from outside the subdivision.

302. Id. at 619 .

303. Id. at 619-20. In stressing that the non-executives should not have sold the executive rights, the court noted, "had the Lesley Appellees retained the executive rights ... the restriction against mineral development would not prohibit them from exercising the rights." Id. at $629 \mathrm{n} .12$ (citing Prop. Owners of Leisure Land, Inc. v. Woolf \& Magee, Inc., 786 S.W.2d 757, 760 (Tex. App. 1990) ("The mineral owner, having the dominant estate, cannot be limited by subdivision restrictions imposed by surface owners after the estate is severed.").

304. Lesley v. Veterans Land Bd. of Tex., 352 S.W.3d 479, 482 (Tex. 2011). For another recent Texas Supreme Court opinion expressing pro-development sentiments in its analysis see Coastal Oil \& Gas Corp. v. Garza Energy Trust, 268 S.W.3d 1, 15-17 (Tex. 2008) (finding the rule of capture prevented recovery for trespass based on allegations that hydraulic fracturing crossed lease lines). "The experts in this case agree on two important things. One is that hydraulic fracturing is not optional; it is essential to the recovery of oil and gas in many areas .... (This fact has recently been brought to the public's attention because of development in the Barnett shale in north Texas, which is entirely dependent on hydraulic fracturing.)." Id. at 16. 
The court's opinion contains no citation following this sentence, and the executives argued the evidence did not support that claim. ${ }^{305}$ Moreover, the executives noted they had not turned down offers to lease because they had not received any offers. ${ }^{306}$ Nonetheless, the court reversed the court of appeals and found the executives had breached their duties in Lesley.

\section{a. A Retreat from In re Bass: The Duty Arises Prior to Leasing and May Require Leasing}

As noted above, the court of appeals in Lesley had relied on In re Bass in ruling that the executive duty had not been triggered because no leases had been executed. The Texas Supreme Court, however, emphasized the unique facts of that earlier opinion and then concluded it cannot "be read to shield the executive from liability for all inaction." 307 However, although the court disapproved of decisions that had held there was no affirmative duty to lease, it stopped short of imposing such a requirement. Instead, the court held:

It may be that an executive cannot be liable to the non-executive for failing to lease minerals when never requested to do so, but an executive's refusal to lease must be examined more carefully. If the refusal is arbitrary or motivated by self-interest to the non-executive's detriment, the executive may have breached his duty.

\section{b. Anti-Drilling Restrictions Cancelled as Remedy for Breach of}

\footnotetext{
305. Lesley, 352 S.W.3d at 482; see also Respondent Bluegreen Southwest One, L.P.'s Motion for Rehearing at $1 \mathrm{n} .1$, Lesley v. Veterans Land Bd. of Tex., 352 S.W.3d 479 (Tex. 2011) (No. 090306), available at http://www.supreme.courts.state.tx.us/ebriefs/09/09030618.pdf ("The evidence regarding the value of the mineral estate consists of one affidavit supplied by [non-executives] in a motion for summary judgment, provided at a time when gas prices were high and speculation regarding the Barnett shale production was high. The Affidavit that is in the record does not take into account whether or not the Barnett shale formation is constant throughout the Property and is a 'best guess' at value and overstates the value. None of the [executives] ever received an offer to lease the Property for any amount of money.").

306. Motion for Rehearing, supra note 305, at $1 \mathrm{n} .1$; see also Oral Argument at 28:18, Lesley v. Veterans Land Bd. of Tex., 352 S.W.3d 479 (Tex. 2011) (No. 09-0306), 2010 WL 3713693.

307. Lesley, 352 S.W.3d at 491 ("While there was an allegation of self-interest in Bass, we concluded that it was not sufficiently supported by the record to warrant compelling discovery of privileged information.").

308. Id. (disapproving of Aurora Petroleum, Inc. v. Newton, 287 S.W.3d 373 (Tex. App. 2009) and Hlavinka v. Hancock, 116 S.W.3d 412 (Tex. App. 2003)).
} 


\section{Executive Duty}

While the Texas Supreme Court recognized that the developer had "acquired the executive right for the specific purpose of protecting the subdivision," it struck the deed restrictions it had imposed. ${ }^{309}$ Relying on Manges, the court found the developer had breached its duty, which it still referred to as fiduciary, by imposing the deed restrictions. ${ }^{310}$ The court concluded "the common law provides appropriate protection to the surface owner through the accommodation doctrine." 311 That courtcreated doctrine provides some protection to pre-existing surface uses against mineral estate dominance in Texas, one of the few majorproducing states without a surface-protection statute. ${ }^{312}$ Whether that doctrine will become necessary or prove useful for lot owners in the Mountain Lakes subdivision remains to be seen. ${ }^{313}$

\section{Implications of Lesley's Retroactive Ruling in the Shale Era}

\section{Acquiring the Executive Right for Surface Protection: A Futile Proposition}

In its motion for rehearing, the developer urged the court to limit the ruling prospectively in light of public reliance on prior law, citing Moser

309. Id. at 491-92.

310. Id. at 491 ("Following Manges, [the court held] that [the developer] breached its duty ... by filing the restrictive covenants.").

311. Id. at 492 .

312. See generally ERnest E. SMith \& JACQueline L. WeAVer, TeXas Law of Oil \& GaS $\S 2.1 . \mathrm{B}(2)$ (b) (2012) (“An unreasonable or excessive use of the surface will give the surface owner an action in damages or a right to an injunction."). The Texas case that established the accommodation doctrine is Getty Oil v. Jones. 470 S.W.2d 618, 622 (Tex. 1971) ("[W]here there is an existing use by the surface owner which would otherwise be precluded or impaired, and where under the established practices in the industry there are alternatives available to the [mineral-estate owner] whereby the minerals can be recovered, the rules of reasonable usage of the surface may require the adoption of an alternative by the lessee."); see also Burney, A Pragmatic Approach, supra note 14, at 63 (discussing the Getty Oil approach and its consequences). For a recent article arguing that Pennsylvania and other Marcellus shale states should adopt the accommodation doctrine, see Paige Anderson, Note, Reasonable Accommodation: Split Estates, Conservation Easements, and Drilling in the Marcellus Shale, 31 VA. ENVTL. L.J. 136, 140-41 (2013) (noting that in light of limited and ineffective legislation protecting surface rights, courts should adopt Texas's version of the accommodation doctrine as set forth in Getty Oil).

313. The Texas Supreme Court remanded the Lesley case for proceedings consistent with its rulings. According to conversations with lawyers involved, the case has settled. 
v. United States Steel Corporation. ${ }^{314}$ In that case, the court overruled the "surface destruction test" for interpreting the phrase "other minerals" in deeds, but restricted the ruling to deeds executed after the date of the opinion in light of public reliance on previous holdings and "an inability to foresee a coming change in the law." 315 The developer in Lesley noted that prior to the decision, acquiring the executive right as a surfaceprotection measure had been literally text book law on which it had been entitled to rely:

It is also possible that the severance of the executive right has nothing to do with a desire to facilitate mineral development. A purchaser who is primarily interested in surface use may insist upon acquiring the exclusive executive right to protect his surface investment.

The court, however, rejected the developer's plea and overruled the motion for rehearing. Therefore, because the court determined that surface owners could rely on the accommodation doctrine but not its deed restrictions, the developer's purchase of the executive right in 1998 proved ineffective for protecting its surface investment. Since the opinion has retroactive effect, other surface owners in Texas, including ranchers and farmers and other developers, may find that their efforts to ensure surface protection - through deeds and wills that consolidated the executive right in one owner-were futile.

\section{Changing Bargains, Expanding Duties and Case-by-Case Results}

By striking the deed restrictions, the executives in Lesley argued the court had ignored their previous bargains, an approach at odds with other Texas Supreme Court opinions. ${ }^{317}$ Specifically, in disputes involving other oil patch transactions, particularly the oil and gas lease, the Texas Supreme Court has declined to rewrite parties' bargains "to achieve what it believes to be a fair contract or to remedy an unwise or improvident

314. Motion for Rehearing, supra note 305, at 5 (citing Moser v. U.S. Steel Corp., 676 S.W.2d 99 (Tex. 1984)).

315. Moser, 676 S.W.2d at 103. In another article I criticized the court's opinion for the prospective ruling in Moser, arguing the public had not relied on cases establishing the "surface destruction test" since it required fact-finding and had changed over time. Burney, Who's On First, supra note 238 , at $712-15$.

316. LOWE ET AL., CASES AND MATERIALS ON OIL AND GAS LAW 602 (6th ed. 2008) (cited in Motion for Rehearing Veterans Land Bd. of Tex., supra note 305, at 3).

317. Motion for Rehearing, supra note 305, at 3 (citing Moser, 676 S.W.2d 99). 
contract." ${ }^{318}$ Following this approach, the court of appeals in Lesley had concluded that the non-executives should be bound by their previous decision to sell their executive rights to a real estate developer. ${ }^{319}$ Endorsing this view in an article written a year after Manges that criticized its use of the fiduciary label, Professor Ernest Smith opined as follows:

For example, in the context of an ordinary land sale, $\ldots$ where the grantee insists on the exclusive executive right in order to protect his surface estate, it seems highly unlikely that the parties expect the executive to act as a fiduciary.... A grantee whose principal concern is surface use will pay a premium for the exclusive executive right. If the grantor, who has retained a nonparticipating share of the mineral estate, can later insist that the executive power be used for his principal benefit, the intent of the transaction has been defeated and the grantor unjustly enriched.'

Yet in Lesley, rather than determine that the grantors-non-executives had been unjustly enriched, the court found the grantee-executive had breached its duty. ${ }^{321}$ Additionally, the court expanded executives' duties by finding they exist prior to leasing and "may" include a duty to lease. ${ }^{322}$ Instead of providing general rules, the court expressly declined to do so because of "the widely differing circumstances." 323 This caseby-case approach, which continues to include the fiduciary standard, ensures that non-executives will file lawsuits claiming executives have breached an enlarged and unpredictable list of duties. ${ }^{324}$ For drafting

318. See id. at 6 n.2; Burney, The Texas Supreme Court and Oil, supra note 273, at 259 (noting the court's refusal to rewrite the oil and gas lease to benefit lessors by implying covenants); see also Danciger Oil \& Ref. Co. v. Powell, 154 S.W.2d 632, 635 (Tex. 1941) (emphasizing that "the court should not read into the [lease] additional provisions unless this be necessary"). See, e.g., HECI Exploration Co. v. Neel, 982 S.W.2d 881, 889 (Tex. 1998).

319. Veterans Land Bd. of Tex. v. Lesley, 281 S.W.3d 602, 625 (Tex. App. 2009) (stating that the non-executives should have understood the terms of the deed, and reversing the trial courts' summary judgment entry to reform the deeds).

320. Smith, supra note 274 , at 373-74.

321. While the Texas Supreme Court's opinion in Lesley notes that the developer had acquired the executive right to protect the subdivision from intrusive development, it does not examine the language in the 1998 deed that conveyed to the executive the "full, complete and sole right to execute oil, gas and minerals leases." Lesley v. Veterans Land Bd. of Tex., 352 S.W.3d 479, 481-82 (Tex. 2011).

322. Id. at 483 .

323. Id. at 491 .

324. Recent cases reflect this fact. See, e.g., Friddle v. Fisher, 378 S.W.3d 475, 478 (Tex. App. 2012) (remanding the case back to the trial court for factual findings regarding duty owed by the executive to the non-participating royalty interest owners when the executive failed to distribute 
future arrangements, in light of Lesley, parties should assess the burdens associated with executive rights before severing and acquiring them in the shale era. ${ }^{325}$

\section{DEED REFORMATION V. INTERPRETATION: ANOTHER LESSON FROM LESLEY}

In addition to reversing the appellate court's rulings regarding the executive duty in Lesley, the Texas Supreme Court reversed the court's ruling declining to reform the 1998 deed. According to the grantors, the Lesleys, the parties intended to reserve a $1 / 4$ mineral interest, not $1 / 8$ as expressed in the deed. ${ }^{326}$ Because the language was clear, the grantors did not ask the court to interpret the deed ${ }^{327}$ - the process involved in resolving the perennial title issues discussed above. ${ }^{328}$ Instead, the

bonus payment); Bradshaw v. Steadfast Fin., L.L.C., 395 S.W.3d 348, 370 (detailing the duties owed by the executive right holder to non-participating royalty interests). For the view that the court exercised "judicial foresight" in Lesley, see Christopher S. Kulander, The Executive Right to Lease Mineral Real Property in Texas Before and After Lesley v. Veterans Land Bd. of Tex., 44 ST. MARY's L.J. 529, 571 (2013) (applauding court's "foresight" in adopting a case-by-case approach but noting litigation will increase).

325. Not all shale-era states will follow Lesley's lead. Louisiana has codified the executive duty and confined it to leasing transactions: "The owner of an executive interest is not obligated to grant a mineral lease, but in doing so, he must act in good faith and in the same manner as a reasonably prudent landowner or mineral servitude owner whose interest is not burdened by a nonexecutive interest." LA. REV. STAT. ANN. § 31:109 (1989). Given the Texas Supreme Court's prodevelopment approach and its treatment of the parties' previous bargain in Lesley, one wonders whether any document prohibiting leasing would be effective in Texas for lands burdened by nonexecutive interests. Instead, developers may have to decline to purchase the property or attempt to buy all of the minerals, an expensive proposition. Other executives, such as parties buying or inheriting mineral interests burdened by pre-existing non-participating royalty interests, face the frustrating position of owing "fiduciary" duties to parties with whom they have had no interaction. See, e.g., Andretta v. West, 415 S.W.2d 638, 641 (Tex. 1967) (imposing a fiduciary relationship between the successors in interest); Friddle, 378 S.W.3d at 482 (finding a fiduciary relationship although there was little to no interaction between the parties).

326. The deed provided that the Lesleys reserved "one-fourth (1/4) of the oil, gas, sulphur and other minerals to which Grantors are now entitled to in all of the lands covered by this conveyance." Lesley, 352 S.W.3d at 484. The Lesleys owned a 1/2 mineral interest, meaning they reserved $1 / 4$ of that $1 / 2$, or a $1 / 8$ mineral interest. $I d$. at 485 .

327. Id. at 485 n.24 ("Lesley does not contend for a favorable construction of the reservation according to its terms, taking into account the inconsistency she asserts.").

328. See generally supra Part II.B. 
Lesleys sought to have the deed reformed to correct the mistake. ${ }^{329}$ This section discusses the differences between interpretation and reformation claims, and suggests that courts should strictly apply or reject the discovery rule in reformation suits in order to preserve the stability of land titles in the shale era.

\section{A. Statutes of Limitations: Applicable to Reformation But Irrelevant to Interpretation}

In interpretation disputes, parties seek legal clarification or declaration about the meaning of words in documents. In reaching determinations, courts follow the rules of document interpretation discussed above, which aid in ascertaining the parties' intent. ${ }^{330}$ However, if a document contains a mistake, meaning one party claims it does not reflect the parties' intent, the proper cause of action is reformation. ${ }^{331}$ Unlike claims seeking interpretation, reformation causes of action are subject to statutes of limitations designed to bar stale claims. $^{332}$ A reformation claim becomes stale when too much time has passed, allowing memories and evidence about the mistake to fade, the classic reason justifying statutes of limitations in general. ${ }^{333}$ Such evidence is irrelevant in document interpretation claims, which involve competing views about the meaning of words, not allegations that words were mistakenly included or omitted. ${ }^{334}$

\footnotetext{
329. Lesley, 352 S.W.3d at 485.

330. See supra Part II.B.

331. ERnest E. Smith \& JacQueline L. WeAver, TeXas LaW OF Oil AND Gas $\$ 3.10$ (2009).

332. See, e.g., Lesley, 352 S.W.3d at 485-86; Brown v. Havard, 593 S.W.2d 939, 943-44 (Tex. 1980).

333. As Justice Holmes explained, statutes of limitations serve the important purpose of "preventing surprises through the revival of claims that have been allowed to slumber until evidence has been lost, memories have faded, and witnesses have disappeared." Order of R.R. Telegraphers v. Ry. Express Agency, 321 U.S. 342, 348-49 (1944); see also Computer Assoc. Int'l, Inc. v. Altai, Inc., 918 S.W.2d 453, 457 (Tex. 1996) (allowing the discovery rule to toll a statute of limitations but only where the injury is "inherently undiscoverable").

334. See Burney, The Regrettable Rebirth, supra note 12, at 78 (explaining that when trying to ascertain the intent of the parties, it "is not the intent that the parties meant but failed to express, but the intention that is expressed").
} 


\section{B. The Discovery Rule and Reformation: When Should Parties to a Deed Know About a Mistake?}

In Lesley, the alleged mistake occurred when the reservation in the deed referred to $1 / 4$ of what the grantors owned; because grantors owned $1 / 2$, and the deed reserved a $1 / 8$ mineral interest. ${ }^{335}$ According to the grantors, the reservation should have stated that they had reserved 1/4. ${ }^{336}$ To correct that mistake, they sought to have the deed reformed. The trial court granted this request but the court of appeals ruled it was barred by the applicable statute of limitations. ${ }^{337}$

As the court of appeals explained, a reformation cause of action involves two elements: "(1) an original agreement and (2) a mutual mistake, made after the original agreement, in reducing the original agreement to writing." 338 In Texas, a four-year statute of limitations applies, but the discovery rule may toll that time period "until the party seeking reformation knew or, in the exercise of reasonable diligence, should have known of the mistake in the deed."339 Because the deed was executed in 1998, and the reformation claim was not filed until 2006, the statute of limitations would bar the Lesleys' claim, unless the discovery rule applied. ${ }^{340}$

\section{Lesley Court of Appeals: No Discovery Rule-Parties Charged With Knowledge When Deed Was Executed}

The court of appeals in Lesley ruled that the discovery rule did not toll the four-year statute of limitations. ${ }^{341}$ In reaching that conclusion, the court noted the Lesleys "knew that they owned a one-half mineral interest before their conveyances to [the developer]. By reading the clear language ... they would have known that they were reserving one-fourth of their one-half mineral interest." 342 Relying on a 1980 Texas Supreme Court decision, Brown v. Havard, the appellate court concluded that if there were mistakes, they "were 'so plainly evident as to charge [the

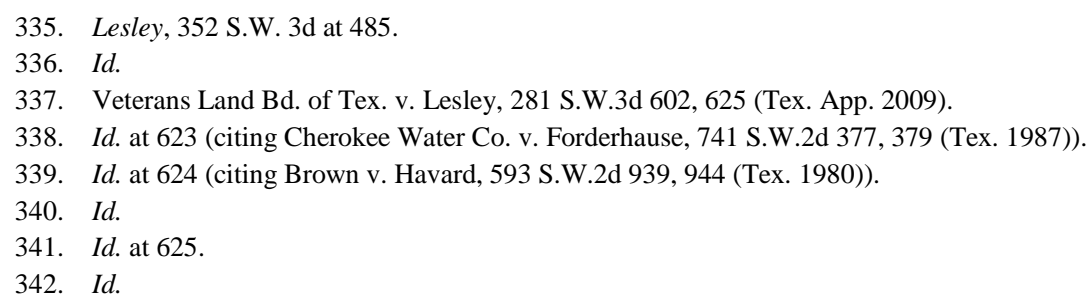


Lesley Appellees] with the legal effect of the words used."

\section{Lesley Texas Supreme Court: Discovery Rule Preserved Reformation Claim}

The Texas Supreme Court disagreed with the court of appeals and held the discovery rule applied. ${ }^{344}$ In reaching its conclusion, the court focused on other language in the 1998 deed that reserved to the grantors $1 / 4$ of all bonuses and delay rentals, which the court noted is "twice the amount to which a one-eighth mineral interest would be entitled." ${ }^{345}$ The court also pointed to subsequent conduct by the developer: the developer had described the reservation in the minerals as $1 / 4$ rather than $1 / 8$ in its own deeds to lot owners. ${ }^{346}$ Like the court of appeals, the supreme court relied on Brown v. Havard. ${ }^{347}$ That case involved a deed containing the double and restated fraction issues discussed above. ${ }^{348}$ In Lesley, the Texas Supreme Court admitted that the mistake in the 1998 deed was not "as opaque as the one in Brown," but decided the discovery rule raised disputed fact issues affecting the reformation claim, and remanded it to the trial court. ${ }^{349}$

\section{An Argument in Support of a Restrictive Approach to the Discovery}

343. Id. (citing Brown, 593 S.W.2d at 944).

344. Lesley v. Veterans Land Bd. of Tex., 352 S.W.3d 479, 486 (Tex. 2011) (noting that the statute of limitations question involves disputed facts instead of flat-out determining that the statute of limitations barred reformation).

345. Id. The deed had reserved $1 / 4$ of the $1 / 2$ of the minerals the grantors owned, which equals $1 / 8$, but continued to state that the grantors reserved $1 / 4$ of bonus and delay rentals. Id.

346. Id. In its motion for rehearing, the developer argued that the court's reliance on subsequent conduct contradicted prior cases and destabilized land titles: "Now title examiners must review documents after the date the deed was executed to determine how later parties may have interpreted even unambiguous deeds, because that subsequent interpretation (even if wrong) can allow an earlier grantor or grantee to use the discovery rule to rewrite the deed." Motion for Rehearing, supra note 305 , at 12 .

347. See Lesley, 352 S.W.3d at 485.

348. Id. at 485-86. The Browns had deed property reserving "an undivided one-half nonparticipating royalty (Being equal to, not less than an undivided 1/16th) of all the oil, gas and other minerals. ..." Brown, 593 S.W.2d at 940 (emphasis omitted). Thirteen years later, the successor to the grantee, Havard, sued seeking interpretation in his favor or reformation. Id. at 941. The Texas Supreme Court held the discovery rule applied and a factual issue existed about when the grantee should have known about the mistake. Id. at 944. The dissent in Brown argued that reformation of the deed was barred by limitations and Havard was not entitled to reformation since he was on notice of what his deed contained. Id. at 948 (McGee, J., dissenting).

349. Lesley, 352 S.W.3d at $485-86$. 


\section{Rule for Reformation Claims: Title Stability in the Shale Era}

The Texas Supreme Court's approach to the discovery rule in Lesley conflicts with the restrictive approach to the discovery rule it has adopted for other oil patch causes of action. In particular, Texas opinions have declined to apply the discovery rule to causes of action that lessors assert against their lessees. ${ }^{350}$ Instead, the court has charged lessors with the burden to obtain knowledge about their lessees' activities from a variety of sources, including public records for oil and gas documents. ${ }^{351}$ If lessors must take these affirmative steps to preserve causes of action under their oil and gas leases, courts should require grantors or grantees claiming reformation to read their deeds within the statutory time period after delivery. ${ }^{352}$

350. See, e.g., HECI Exploration Co. v. Neel, 982 S.W.2d 881, 886 (Tex. 1998) (noting that courts have tolled the statute of limitations where information was fraudulently concealed from a lessee).

351. See, e.g., id.; Shell Oil Co. v. Ross, 356 S.W.3d 924, 928 (Tex. 2011) ("Reasonable diligence requires that owners of property interests make themselves aware of relevant information [regarding royalties] available in the public record."); Wagner \& Brown, Ltd. v. Horwood, 58 S.W.3d 732, 737 (Tex. 2001) (noting that there are sources available from which royalty owners may obtain information about royalty calculations from their lessees); see also Samson Lone Star, Ltd. v. Hooks, 389 S.W.3d 409, 441-42 (Tex. App. 2012) (criticizing the supreme court's approach to the discovery rule as applied to lessors). Justice Jim Sharp provided:

I reluctantly concur, based on the Texas Supreme Court's holding in BP America Production Co. v. Marshall, 342 S.W.3d 59 (Tex.2011). In that case, the Texas Supreme Court makes clear that no lies on the part of a lessee, however self-serving and egregious, are sufficient to toll limitations, as long as it is technically possible for the lessor to have discovered the lie by resort to the Railroad Commission records. This burden the Court imposes upon lessors is severe. It is now a lessor's duty to presume that any statement made by its lessee is false and to ransack the esoteric and oft-changing records at the Railroad Commission to discover the truth or falsity of its lessee's statements. If, as is often the case, these records are technical in nature and require expert review to ferret out the truth, it is the lessor's job to hire experts out of its own pocket to perform such a review. If a lessor fails to take these steps, then it will have failed in exercising reasonable diligence to protect its mineral interests and, if the lessee's fraud is successful for longer than the limitations period, the lessor's claims will be barred by limitations.

$I d$.

352. This should at least be the case when the basis for reformation is mistake, rather than fraud or misrepresentation, which provide other grounds for challenging a deed. Moreover, even if the statute of limitations does not bar the claim, or was not raised as a defense, parties must still meet their burden of proof. See Arndt v. Maki, 813 N.W.2d 564, 572 (N.D. 2012) (affirming trial court ruling that evidence was insufficient to support reformation of 1984 deed that did not contain a mineral reservation); Van Berkom v. Cordonnier, 807 N.W.2d 802, 806 (N.D. 2011) (affirming trial 
Shale era production may motivate grantors and grantees to review their deeds for mistakes as required for reformation claims. ${ }^{353}$ A liberal approach to the discovery rule potentially preserves and encourages these claims by allowing parties to ignore mistakes for years after deeds were executed. The court of appeals' approach in Lesley charges parties with knowledge they would have obtained had they read their deeds on the date of execution. That approach reflects general views charging parties with knowledge about documents they sign. ${ }^{354}$ It also promotes title stability by preventing potential changes in ownership years after title examiners have based decisions on plain terms in the four-corners of deeds. To promote title stability, courts should strictly apply statutes of limitations and limit the discovery rule for deed reformation claims in the shale era.

\section{CONCLUSION}

Along with oil and gas production, the shale-play booms guarantee a surge of oil and gas title disputes involving the perennial issues discussed above. States with long histories of production and case law have grappled with several of these issues, providing answers for some and confusion regarding others. In particular, executive-right owners may find that the Texas Supreme Court's opinion in Lesley has burdened them with duties for which they had not bargained, and that owning that right provides no value as a surface-protection measure. However, title examiners can take comfort in other Texas decisions that appear to have finally rejected the two-grant doctrine for interpreting conflicting

court ruling that evidence was insufficient to prove mineral reservation was mistakenly omitted from a 1995 warranty deed).

353. For a recent case see Dupnik v. Hermis, involving land in the Eagle Ford shale in south Texas. No. 04-12-00417-CV, 2013 WL 979199 (Tex. App. Mar. 13, 2013). The issue in that case was whether a deed had reserved the minerals or conveyed the surface and the minerals to a described tract. Id. at $* 1$. The deed described the land, but in the reservation section the word "none" appeared. Id. An exhibit, however, noted the property conveyed was "surface only." Id. Although the case confusingly focuses on whether the deed was void or voidable, and does not mention reformation, it rejects application of the discovery rule, finding the parties should have read their deed when it was executed. Id. at *2-4.

354. ERnest E. SMith \& JACQUELINE LANG WeAVER, TeXAs LAW OF OIL AND Gas $§ 3.10$, at 3-79 (2009) ("The most common defense to a suit for reformation is the statute of limitations ... but there is often a dispute over when the statute began to run. Of course the statute of limitations presumptively begins running immediately on the deed's execution and delivery. Because the parties to the deed are charged with knowledge of its contents, this presumption is virtually irrebutable if the deed clearly and obviously deviates from the parties' agreement"). 
fractions in multiclause deed forms. Yet that state has not fully clarified how title examiners and courts should interpret deeds with double or restated fractions, which invariably are multiples of the usual 1/8 landowner's royalty. As I argue, while that lease royalty is now more historic than usual, courts should incorporate an understanding of the legacy of that $1 / 8$ royalty into the interpretation process. That approach ensures results more consistent with the over-arching goal of deed interpretation: ascertaining the parties' intent. In addition to that interpretative goal, however, courts should adopt rules that promote another goal: title stability. For example, the Texas approach to the mineral or royalty issue promotes that goal by according set meaning to the royalty and mineral labels, one that does not vary with outside evidence. On the contrary, the Oklahoma approach allows the meaning of those words to vary depending upon whether a lease pre-dated the deed. That approach complicates titles by requiring title examiners to review outside evidence and determine ownership on a case-by-case basis.

Instead, in the shale era courts, should embrace the goal of ensuring title stability by rejecting rules that require scrutiny of extraneous evidence and that motivate strained interpretations. For example, Kansas courts stretched for a mineral interpretation to avoid the application of the rule against perpetuities to non-participating royalty interests. Kansas courts should complete the process started in Rucker and declare that non-participating royalty interests - common oil-patch interests-are vested interests immune from the common law rule against perpetuities. Regarding the meaning of "minerals," Pennsylvania acknowledged the extent of public reliance on the Dunham rule and reaffirmed it for Marcellus shale disputes in that state. However, the rule retains rule of construction traits, which permits consideration of outside evidence regarding the parties' intent. Fortunately, the courts' restrictive approach to the rule in practice, which confines interpretation disputes to the deed, should promote title stability. Another lesson from Lesley regarding title stability is the value of a strict approach to the discovery rule in deed reformation actions, one that requires grantors and grantees to discover mistakes in their deeds within a state's set statute of limitations period. In addition to providing guidance to courts, Lesley and other cases discussed in this article provide valuable drafting lessons about perennial issues in oil, gas and mineral deeds. More lessons will follow as courts address the inevitable boom in title litigation spawned by the shale revolution. 